NBER WORKING PAPER SERIES

\title{
BUFFALO HUNT: INTERNATIONAL TRADE AND THE VIRTUAL EXTINCTION OF THE NORTH AMERICAN BISON
}

\author{
M. Scott Taylor \\ Working Paper 12969 \\ http://www.nber.org/papers/w12969 \\ NATIONAL BUREAU OF ECONOMIC RESEARCH \\ 1050 Massachusetts Avenue \\ Cambridge, MA 02138 \\ March 2007
}

I am grateful to seminar participants at the University of British Columbia, the University of Calgary, the Environmental Economics workshop at the NBER Summer Institute 2006, the fall 2006 meetings of the NBER ITI group, and participants at the SURED II conference in Ascona Switzerland. Thanks also to Chris Auld, Ed Barbier, John Boyce, Ann Carlos, Charlie Kolstad, Herb Emery, Mukesh Eswaran, Francisco Gonzalez, Keith Head, Frank Lewis, Mike McKee, and Sjak Smulders for comments; to Michael Ferrantino for access to the International Trade Commission's library; and to Margarita Gres, Amanda McKee, Jeffrey Swartz, Judy Hasse of Buffalo Horn Ranch and Andy Strangeman of Investra Ltd. for research assistance. Funding for this research was provided by the SSHRC. The views expressed herein are those of the author(s) and do not necessarily reflect the views of the National Bureau of Economic Research.

(C) 2007 by M. Scott Taylor. All rights reserved. Short sections of text, not to exceed two paragraphs, may be quoted without explicit permission provided that full credit, including $\odot$ notice, is given to the source. 
Buffalo Hunt: International Trade and the Virtual Extinction of the North American Bison

M. Scott Taylor

NBER Working Paper No. 12969

March 2007

JEL No. F1,Q2,Q5,Q56

\begin{abstract}
$\underline{\text { ABSTRACT }}$
In the 16th century, North America contained 25-30 million buffalo; by the late 19th century less than 100 remained. While removing the buffalo east of the Mississippi took settlers over 100 years, the remaining 10 to 15 million buffalo on the Great Plains were killed in a punctuated slaughter in a little more than 10 years. I employ theory, data from international trade statistics, and first person accounts to argue that the slaughter on the plains was initiated by a foreign-made innovation and fueled by a foreign demand for industrial leather. Ironically, the ultimate cause of this sad chapter in American environmental history was of European, and not American, origin.
\end{abstract}

\author{
M. Scott Taylor \\ IEE Canada Research Chair \\ Department of Economics \\ The University of Calgary \\ 2500 University Drive, N.W. \\ Calgary, Alberta Canada \\ T2N $1 \mathrm{~N} 4$ \\ and NBER \\ mstaylor@ucalgary.ca
}




\section{Introduction}

200 YEARS AGO, Meriwether Lewis and William Clark completed their epic voyage of Western discovery. Their vivid account of the West's natural beauty and its limitless wealth spurred on thousands of Americans to carve out a new life and new nation west of the Mississippi. Westward expansion with its stories of frontier hardship have shaped much of American national identity by showing how self-reliance, risk-taking and hard work could tame a wild frontier. While the 19th century is surely one of the most inspirational periods in American history, it also bears witness to a less flattering record with regard to the environment: most significantly, the slaughter of the plains bison, or buffalo. ${ }^{1}$

This paper examines the slaughter using theory, empirics, and first person accounts from diaries and other historical documents. It argues that the story of the buffalo slaughter is surprisingly not, at bottom, an American one. Instead I argue that the slaughter on the plains was initiated by a tanning innovation created in Europe, and maintained by a robust European demand for buffalo hides. These market forces overwhelmed the ability of a young and still expanding nation, just out of a bloody civil war, to carefully steward its natural resources.

Specifically, I argue that three conditions are jointly necessary and sufficient to explain the time pattern of buffalo destruction witnessed in the nineteenth century. These are: (1) a price for buffalo products that was largely invariant to changes in supply; (2) open access conditions with no regulation of the buffalo kill; and (3), a newly invented tanning process that made buffalo hides into valuable commercial leather.

In the 16th century, North America contained 25-30 million buffalo; by the late 1880s less than 100 remained wild in the Great Plains states. ${ }^{2}$ While removing buffalo east of the Mississippi took settlers over a 100 years, the remaining 10 to 15 million were killed in a punctuated slaughter in a little

\footnotetext{
${ }^{1}$ The term buffalo is a misnomer but I will use it throughout since this is common usage. The description of the kill as a slaughter is also conventional. It is perhaps wise to inform the reader at the outset that this paper is concerned exclusively with positive questions. I leave it to the reader to determine for themselves whether the slaughter was unfortunate or inevitable.

${ }^{2}$ The species Bison bison comes with two distinct varieties: the common Plains bison (Bison, bison, bison ) and the less common Woods bison (Bison, bison, athabascae) found exclusively in Canada. I focus on the extinction of the plains bison or buffalo in the U.S., leaving an examination of the Canadian case for future work.
} 
over 10 years. Standard explanations hold some combination of U.S. Army policy, the Railroads, and changes in native hunting practices responsible. My claim is that (1), (2) and (3) are both necessary and sufficient.

The argument I develop proceeds in three steps. First I build a novel model of buffalo hunting. It assumes potential buffalo hunters differ in their hunting skill, and allows for easy entry and exit. Entry and exit from hunting was common, and skill differences across hunters is an important part of the historical record. ${ }^{3}$ For the most part, I take world prices as given and assume throughout that there are no controls over hunting. The model is made general equilibrium by the addition of a numeraire good sector which serves as the outside option for potential buffalo hunters. The general equilibrium structure is helpful to our discussion of export flows, and necessary for our construction of an autarky counterfactual.

The theory delivers two key results. First, it shows how the combination of an innovation in tanning, fixed world prices for hides, and open access to the herds proved fatal to the buffalo. The innovation in tanning creates frenzied entry into hunting, the buffalo herds decline rapidly, and the "harvest" of buffalo hides for export booms. ${ }^{4}$ Fixed prices ensure the new supply of buffalo hides cannot dampen the incentive to hunt; open access ensures that regulations limiting the kill are not forthcoming; and the tanning innovation plus hunter heterogeneity delivers a punctuated slaughter followed by rapid exit. Rigid prices, no controls on hunting, and a slaughter compressed in time are important and verifiable features of the historical record.

Second, the theory show how rigid prices are necessary for the story. An unexpected innovation is just not enough. For example, if prices adjust considerably to changes in supply - as they typically would if buffalo products had only a domestic market - then the number of hunters can rise over time even as the buffalo are wiped out. The "punctuated slaughter" is relatively smooth over time, and hide prices rise as the buffalo approach extinction. All of these predictions are inconsistent with the historical record: hide prices fell slightly over the period; there was massive entry and then exit; and the

\footnotetext{
${ }^{3}$ The model is most closely related to Brander and Taylor (1997), but bears some resemblance to resource models with entry such as Wilen (1976) or Brander and Taylor (1998).

${ }^{4}$ The pace of the slaughter was such that many contemporary writers thought extinction was all but inevitable. Allen, writing in 1876, said "The fate of none of our larger animals is more interesting than is that of the bison, since total extermination is eventually surer to none than to this former "monarch of the prairies." p. 71 Allen (1876)
} 
slaughter was in fact just that.

In sum the theory provides a prima facie case for the importance of international markets in the slaughter, and directs us to look at international trade statistics for empirical evidence. Accordingly, the second step is to examine evidence on U.S. exports of buffalo hides.

A natural consequence of the rapid elimination of the buffalo is that records of the number killed are non-existent, and only very partial shipping records exist. U.S. trade statistics from the 19th century contain categories of exports that contain buffalo products, but no individual entry is labelled buffalo meat, buffalo robes or buffalo hides. The key series I employ is "hide and skins exports" and this surely contains both cattle and buffalo hides. To solve this problem, I employ economic theory and independent work on the U.S. cattle cycle to construct a time series of buffalo hide exports from the overall export figures. This constructed series is then cross-checked for consistency against several pieces of independent evidence. The cross checks examine the magnitude of the implied exports, their timing, and their geographic variation. I find direct supporting evidence of buffalo hide exports in newspaper accounts, personal diaries, and business directories in importing countries. In addition, I examine import data from Canada, the UK, and France that corroborate my findings. These numerous independent checks lend support to the constructed series.

The final step in the argument is to examine the main alternative hypotheses in light of our new data. While the model's analytic results prove that my three conditions are sufficient to generate the slaughter they do not prove necessity. To argue for necessity, I show that the new constructed export data strongly support the export-driven slaughter hypothesis. The magnitudes of the export flows are considerable. Approximately 6 million buffalo hides are exported over the 1871-1883 period and this represents a buffalo kill of almost 9 million. The timing of greatest export flows fits the historical record extremely well. I then discuss the three major alternative hypotheses and argue that they do far less well in matching the data.

There is of course a huge literature studying the buffalo and other related aspects of westward expansion in the 19th century. This literature includes many contributions from history, political science and sociology but only a handful of contributions from economics. Perhaps the best known contribution is the 1889 monograph by William Temple Hornaday who was then the chief taxidermist of the Smithsonian Institute. Hornaday's monograph "The Extermination of the American Bison" is the classic account of the 
elimination of the buffalo both east and west of the Mississippi. Hornaday collects figures on the number killed from various sources, and provides the first definitive account of the slaughter. Hornaday's account however make no mention of international trade. Other classic contributions such as "The Plains of the Great West" by Richard Irving Dodge (1877), and Joel Allen's 1876 contribution "The American Bisons: Living and Extinct" offer us first person accounts (in the case of Dodge), and a scholarly examination of the process from a naturalist at Harvard, but neither seek to identify the underlying cause.

More recent work by economists include Dean Lueck (2002) and Bruce Benson (2006) who focus on property rights issues, and a series of papers by economic historians linking market forces to overuse and depletion of renewable resources in earlier centuries. ${ }^{5}$ Prominent among these are the series of papers by Carlos and Lewis $(1993,1999)$ who examine the depletion of beaver in the 18th century; Patterson and Wilen (1977) who study the northern pacific fur seal hunt; and most recently Allen and Keay (2004) who study the extinction of the Arctic Bowhead whale.

The work presented here differs from earlier contributions in several ways. Most importantly the focus here is on the "slaughter." There is no real mystery as to why the buffalo were eliminated from their previous ranges - an expanding population, conversion to agriculture, and industrialization all spelt the end for the buffalo sometime during the late 19th or early 20th century. What is surprising is the rate of killing and its variation over time: one half of the pre-contact buffalo population was killed in just ten years time post 1870; the elimination of the other half took over 100 years.

This focus on the slaughter is important, and absent from the other contributions. It is important, because a rapid slaughter greatly constrains the ability of governments and agents to respond and strengthen property rights institutions. The existence of the slaughter also leads one to ask why markets didn't adjust to the huge increase in the supply of buffalo products and thereby slow the carnage. A focus on the slaughter naturally suggests international markets may have soaked up the excess supply while keeping prices constant. Investigation of this possibility led to the major contribution of this work: the identification of international trade as a key driver in the process.

\footnotetext{
${ }^{5}$ An early and excellent discussion of the slaughter, the hide trade, and the attempts to legislate hunting is contained in Hanner (1981).
} 
The earlier contributions from economic history explored rather different positive and normative questions concerning resource depletion. Carlos and Lewis link variation in depletion rates across trading posts to differences in local competition; Patterson and Wilen examine how international rivalry and transboundary issues affect depletion; and Allen and Keay ask whether depletion could have been avoided by enlightened public policy. In each case there was little debate as to the ultimate source of depletion. The Bowhead whale was eliminated by Dutch and English whalers over almost three centuries; while the beaver and seal were depleted by the fur trade, albeit with the help of new technologies. In contrast, I argue that the usual suspects held responsible for the slaughter on the plains - the Railroads, the U.S. Army, Environmental change or altered native hunting practices - are in fact innocent.

An examination of the slaughter also provides important case study evidence on the speed with which property rights institutions can adapt in the face of new circumstances. In this case the changed circumstance was an innovation, and the adjustment, as measured by new regulation, was slow. In contrast, market responses were immediate and powerful. This relative speed of adjustment is key to many policy debates. For example, even when property rights over resources are absent or poorly enforced prior to a trade liberalization, access to world markets may lead to a strengthening of protection. It may do so because world markets often value domestic resources very highly and this provides an incentive to improve resource management. If this protection is soon forthcoming, then opening up to world markets can provide both conventional gains from trade and improved resource management. ${ }^{6}$ This tantalizing possibility is however just that - a theoretical possibility, since there is currently very little empirical evidence directly linking changes in property rights protection, resource use, and trade liberalization. Indirect evidence can be gleaned from the empirical literature on trade and the environment, the related literature linking income gains to pollution reduction, and a handful of specific studies questioning the simple link between lax property rights and resource over use. ${ }^{7}$

Given the dearth of empirical evidence directly on point, case study evidence is of great value. Looking back to our past provides us with guidance

\footnotetext{
${ }^{6}$ See Copeland and Taylor (2004b) for a model with these features.

${ }^{7}$ On trade, see Copeland and Taylor (2004a); on improved protection, see Grossman and Krueger (1995); on property rights see Besley (1995); and on the links between protection and resource over use see Bohn and Deacon (2003) and UNEP (2001).
} 
for the future. For in the not too distant past, Europe was the high income developed region, while America was a young still developing country. In the 1870s, America was a large resource exporter with little or no environmental regulation, while Europe was a high income consumer of U.S. resource products apparently indifferent to the impact their consumption had on America's natural resources. Written in this way it is apparent that the story of the buffalo has as much relevance today as it did 130 years ago. Many developing countries in the world today are heavily reliant on resource exports, are struggling with active or recently past civil wars fueled by racial strife, and few, if any, have stringent regulations governing resource use. The globalization pressures these nations face today, and the policy choices they have to make, are not too different from those facing the U.S. in the late 19th century.

The rest of the paper proceeds as follows. In section 2, I set out important background material on the history and biology of the buffalo which is generally not known. In section 3 , I construct the hunting model to examine how the time path of buffalo kills responds to an unexpected tanning innovation. In section $4 \mathrm{I}$ construct the buffalo-hide-export data, and provide a series of cross-checks. Section 5 considers alternative hypotheses, while section 6 concludes. Two appendices follow.

\section{History and Biology}

Buffalo are the largest terrestrial mammals in North America, and have been since the Pleistocene extinctions over 10,000 years ago. Earliest recorded European observations came from Spanish explorers in the early 1500s who remarked on the vast herds of native cattle in present day Mexico. Similar observations were subsequently made by French and English explorers in other regions of North America. The newcomers were unanimous in their appraisal of buffalo as "innumberable" or "countless" and the country was famously described as "one black robe" of buffalo.

The American explorers, Lewis and Clark, met buffalo at many points along their voyage of discovery. On their return voyage in 1806 at the mouth of the Yellowstone river where it meets the Missouri, they recorded: "The buffalo now appear in vast numbers. A herd happened to be on their way across the river [the Missouri]. Such was the multitude of these animals that although the river, including an island over which they passed, was a 
mile in length, the herd stretched as thick as they could swim completely from one side to the other, and the party was obliged to stop for an hour."

Since extrapolating from any first person account can lead to serious error, it is not surprising then that early estimates of the buffalo population vary from over 100 million to less than 20 million. ${ }^{8}$ The most reliable population estimates come to a figure somewhere between 25 and 30 million buffalo. The estimates are constructed by multiplying the carrying capacity on agricultural land with estimates of the original buffalo range of almost 3 million square miles. Buffalo were in all of the lower 48 (save the New England states), the four westernmost Canadian provinces and its two territories, and the northernmost part of present day Mexico.

\subsection{Habitat Destruction and Subsistence Hunting}

The buffalo east of the Mississippi were removed by a combination of habitat destruction and subsistence hunting. The gradual removal of buffalo proceeded westward when settlers crossed the Allegheny mountains into Kentucky in the early 1800s. It continued unabated for the next fifty years as settlers moved towards the "Great Plains" at approximately the 98th meridian. By 1820 or 1830, buffalo were largely gone east of the Mississippi. During much of this early period natives hunted the buffalo not only for their own subsistence needs but also to trade buffalo robes at forts and towns. A buffalo robe is the thick and dark coat of a buffalo that is killed in mid winter. Robes could be used as throws for carriages, or cut to make buffalo coats and other fur items. They were a popular item in the 19th century and they made their way to eastern markets by transport along the Missouri river to St. Louis or overland via the Santa Fe trail. In the 1840s settlers pushed through the Great Plains into Oregon and California. The movement of the 49ers to California and the Nevada gold rush years brought a steady stream of traffic through the Platte river valley. Subsistence hunting along the trail plus the movement of cattle and supplies, divided the existing buffalo herd into what became known as the Southern and Northern herds.

The division of herds became permanent with the building of the Union Pacific railroad through the Platte River valley in the 1860s. The railroad

\footnotetext{
${ }^{8}$ The naturalist Thomas Seton (1909) estimated the population circa 1600 at 75 million, but with little factual basis. The historian Dan Flores (1991) employed a more transparent method to arrive at a figure of 27 million.
} 
created a local demand for buffalo meat, and brought sport hunters, inquisitive easterners and foreign dignitaries eager to go out West on a buffalo hunt. While subsistence hunting for the railroad crews surely had some effect on buffalo numbers, as did the railroad's popular day trips to kill buffalo, the harried buffalo herds withdrew from the tracks creating a 50 mile wide corridor centered on the Union Pacific line. ${ }^{9}$ The railroads also provided transportation for buffalo products to eastern and foreign markets, but in the 1860s railway cars were not refrigerated, and hence buffalo meat was only marketed as salted, cured or smoked.

Despite the railroads, the market for buffalo robes, the increase in subsistence hunting, and the conversion of the high prairie to agriculture, Utley notes that "contemporaries detected no major reduction in the abundance of the species. Most observers thought the killing was not greater than the natural increase of the species and expected the extermination of the buffalo from the High Plains would occur gradually over a span of decades in a manner similar to what had happened east of the 99th meridian."10 The force of habitat destruction was minimal on the Great Plains. In 1860, they held only 164 thousand people on an area of 416 million acres. Farms were less than $1 \%$ of the land area.

The Civil War brought a temporary reprieve for the buffalo. Major battles occurred in regions with few or no buffalo, and these years provided a break from the slow but steady destruction that had marched westward. Despite this reprieve, settlement and habitat destruction had taken some toll: estimates of the buffalo population in 1865 range from 10 to 15 million.

\footnotetext{
${ }^{9}$ To see why subsistence and sport hunting could make only a small dent in the herd a little calculation is helpful. If the carrying capacity of the Great Plains was 15 million buffalo, and if we take their intrinsic growth rate at .2, then (using the logistic growth equation for the buffalo) a maximum sustainable yield population of 7.5 million allows for a yearly sustainable kill of 750,000 buffalo. To put this in perspective, the most famous buffalo hunter ever known - Buffalo Bill Cody - was an entrepreunial young boy of 18 when he offerred to supply the Union Pacific workers with buffalo meat. William Cody got the contract with Union Pacific, but even his own (perhaps inflated) accounts indicate he killed only 4 to 5 thousand buffalo per year. Hornaday claims that killing by whites, natives and half-breeds totalled less than 500,000 before 1870 and was sustainable (Hornaday, (1889) p.466.) .

${ }^{10}$ See Utley (2003), p. 243.
} 


\subsection{The Innovation}

The temporary reprieve ended quickly when in 1870 or 1871 tanners in England and Germany developed a method for tanning buffalo hides into useful leather. While natives had always been able to tan the thick haired buffalo hides taken in winter months into buffalo robes, their process was laborious and required ingredients from buffalo themselves (the brain, liver, and fat or tallow). A cheap simple commercial process was as yet unknown. Various historical accounts attribute the breakthrough to tanners in Germany and still others to English tanners. Many accounts suggest the "innovation" was soon imitated by U.S. tanners, but exactly when and where is unclear.

There are several elements of the innovation that are important to discuss: its timing, the initial location of the innovation in one or more foreign countries, the fact that it represented a shock to the buffalo hunting industry, the use to which buffalo hides were put once tanned, and the eventual diffusion of the innovation to other countries.

The hardest evidence for timing and location is given by a London Times article reporting from New York city in August of 1872. It reports that a few enterprising New Yorkers thought that buffalo hides might be tanned for leather, and when the hides arrived they were "sent to several of the more prominent tanners who experimented upon them in various ways, but they met with no success. Either from want of knowledge or a lack of proper materials, they were unable to render the hides soft or pliable, and therefore they were of no use to them."

The report continues to note "several bales of these hides were sent to England, where they were readily taken up and orders were immediately sent to this country for 10,000 additional hides. These orders were fulfilled, and since then the trade has continued." Further still, the methods are spelt out "The hides are collected in the West by the agents of Eastern houses; they are simply dried, and then forwarded to either New York or Baltimore for export...The low price that these goods have reached on the English market, and the prospect of a still further decline, may in time put an end to this trade, but at present the hides are hunted for vigorously, and, if it continues, it will take but a few years to wipe the herds out of existence (my emphasis)."11

\footnotetext{
${ }^{11}$ It appears this article is unknown to other researchers: see "Buffalo Hides: Some eight or ten months ago", The Times, August 17, 1872, pg. 4, Issue 27458, col. F. It is not known who the enterprising New Yorkers were, although one possibility is William C.
} 
A secondary account comes from Gard (1960, p.90) "In 1870, J. N. DuBois, a Kansas City dealer in hides, furs and wool shipped several bales of buffalo hides to Germany, where tanners had developed a process for making them into good leather. Other orders followed, and soon some American tanners either learned of this process or developed a similar one of their own. In the spring of 1871, DuBois sent hundreds of circulars out to the buffalo ranges, offering to buy at attractive price all hides taken at any time of the year. DuBois also encouraged the hunters by telling them how to peg the hides, flesh side up, for drying. In addition, he sold them a poison, imported from South America, to kill the bugs that infested and damaged many of the hides." 12

Putting these together it appears the innovation was made in England and Germany at roughly the same time in 1871. Importantly, U.S. tanners were unable to tan buffalo hides at this time.

The fact that the innovation was an unexpected shock is of little doubt, and supported by many accounts. The account of buffalo hunter George "Hodoo" Brown is especially on point as it provides evidence on both the timing and unexpectedness of the innovation. When returning from a meat hunting trip in May of 1871 to Fort Wallace, Brown had the following conversation with fellow hunters at the fort:

"We told them the weather was getting so warm it was almost impossible to get meat to market before it spoiled. They said to me, 'Why don't you skin them and just take the hides, and let the meat lay?' I says, 'What the devil would I do with the hides?' One man said, 'Ship them to Leavenworth to W.C. Lobenstine. He'll buy your hides and send a check'. So Burdett and I on our next trip went to skinning." 13

Other accounts attest to the unexpectedness of the innovation and the introduction of buffalo hides as a valuable commodity. It is less clear however how buffalo tanned leather was used, and why it had such a strong foreign demand. The literature mentions two uses for the leather. The first was for sole leather, with a burgeoning European demand coming from refitting

Lobenstein (a pelt dealer with an office in Levingworth Kansas) who "is well known as the first dealer to introduce buffalo hides to the market" Fort Griffin Echo, April 19th, 1879. Lobenstein later lived on the Upper East side of Manhattan.

${ }^{12}$ Spoilage was a problem. Green hides collected by farmers and hunters soon rotted. Once commercial tanning was available, hides could be preserved before tanning by placing them in a lime solution. This removed hair and facilitated shipping as a wet hide.

${ }^{13}$ Interview with George W. Brown reported in Gilbert et al. (2003), page 55. 
armies in the post 1870 period. Specifically, several sources mention the British Army and its demand for buffalo leather as it was tougher and thicker than cow hide.

Buffalo hunter John R. Cook's account attests to this view. Cook recounts his conversation with J.L. Hickey (a buying agent of W.C. Lobenstine the hide dealer mentioned above) when the two of them brought in Cook's hides for transport. "In a few moments we were saddled up and off. I found him to be a good conversationalist, well informed and in possession of knowledge upon the latest current events. He said all of Loganstein [sic] \& Company's hides went to Europe, that all the English Army accouterments of leather were being replaced with buffalo leather."14

In addition to sole leather, the tough buffalo hides found use as industrial belting for machinery in England and elsewhere on the continent. Many secondary sources make this connection, but primary source evidence is also available from English business directories. For example, Slater's Royal National Commercial Directories at the time list numerous tanners, hide merchants, and leather belt manufacturers in their directory of trades. These businesses list as products buffalo hides, buffalo skips, buffalo hide shavings, buffalo pickers, and strapping for cotton gins. ${ }^{15}$

The eventual diffusion of the innovation to tanners in the U.S. and other European countries is more difficult to establish, although often claimed in the literature (recall for example Gard's account). The best evidence of diffusion of the innovation to U.S. tanners comes from NY Chamber of Commerce Annual reports that list price quotes for hemlock tanned sole leather made from a variety of hides (Buenos Ayres, California, etc.). These price quotes do not include bison in the early 1870s, but price quotes for bison tanned leather soles first appear in the $1877 / 1878$ report, continue for 1878/1879, and then disappear the following year. This suggests the innovation may have diffused to U.S. tanners by the late 1870 s. $^{16}$

\footnotetext{
${ }^{14}$ Excerpted from Cook, John R. The Border and the Buffalo, Crane and Company, Topeka, 1907. Reprint by State House Press, Austin, 1989. Primary evidence for Hickey's role in the hide trade is found in numerous ads placed in the Fort Griffin Echo listing him as a buying agent for W.C. Lobenstein.

${ }^{15}$ See for example in Slaters Business Directory, 1879 for Manchester and Salford, advertising by John Tullis \& Son Tanners and Curriers and Leather Belt Manufacturers, p.80; the list of hide dealers and merchants, p.103; the advertising by Heyworth \& Law Tanners and Curriers and manufacturers of Machine Belting, p.126; the advertising of Hepburn \& Sons, Tanners and Curriers \& Leather Factors, p.85.

${ }^{16}$ I say "may have" since the U.S. was importing large volumes of leather products
} 
Evidence for diffusion to other countries is also difficult to establish, but here again business directories help. For example, the Foreign Appendix to Slater's Business Directory of London in 1884 lists the Poullain Brothers of Paris as Tanners specializing in straps and leather for steam works and buffalo leather rubbers for spinning mills. Given the diffusion to U.S. tanners in the 1870s and the close proximity of most European countries, diffusion from England and Germany to other countries seems highly likely.

\subsection{The Flint Hide Market}

Regardless of the innovation's source, its effect on the Great Plains was electrifying. The market for buffalo hides boomed; buffalo hunters already in the field - like George "Hodoo" Brown - started to skin buffalo for their flint (hairless) hides, and hundreds if not thousands of others soon joined in the hunt. Previous to the innovation, hides taken from the Southern Herd or hides taken in all but three winter months were virtually worthless as fur items. The only saleable commodity from a buffalo killed in these regions or times was its meat, but this market was severely limited by transportation costs. With the advent of a flint-hide market, killing a buffalo anywhere and at anytime became a profitable venture. By 1872 a full scale hide-boom was in progress.

Although no accurate figures are available, Colonel Richard Irving Dodge (of Dodge city fame) estimated the buffalo kill in Kansas at close to 3.5 million buffalo over the $1872-1874$ period. ${ }^{17}$ Once the herd in Kansas disappeared the hunters turned south. Reports of large herds south of the Arkansas river, lured hunters into land granted to the Comanches in the Medicine Lodge Treaty of 1867. Hunting south of the Arkansas was a dangerous game and a major battle between hide hunters and Comanches occurred at Adobe walls in June of 1874. A short buffalo war ensued, but the U.S. Army eliminated the Indian threat by 1875. In doing so the Army opened up the whole of present day Oklahoma, western Texas and eastern New Mexico to the hide hunters.

The business of hide hunting did not last long - less than 7 years in Kansas and areas to the south. And when the Southern Herd was eliminated in 1879, many hide hunters looked north to the only significant herd left in existence.

at this time and the bison sole leather could have been imported rather than produced domestically.

${ }^{17}$ See Dodge (1877). 
The key bottleneck in the north was the still hostile Sioux. After the defeat of the Sioux in the late 1870s, the Northern Pacific Railroad extended its tracks west from Bismarck into the heart of the Montana plains reaching Glendive in 1880 and Miles City in 1881. The Northern Herd was already diminished by the robe trade that, as early as 1850 , sent 200,000 to 300,000 robes yearly down the Missouri. ${ }^{18}$ With easy transportation and the elimination of the Indian threat, hide hunters flooded the northern range. Hide hunting in the north reached a peak in 1881 or 1882, and by 1883 the commercial hide hunt was faltering. In 1884, the last of the flint hides were shipped east. ${ }^{19}$

\subsection{The Road to Conservation}

In 1886, William Templeton Hornaday urged his superiors at the Smithsonian to fund an expedition to kill and mount a grouping of buffalo for posterity. Although it took Hornaday two expeditions, four months of effort, and the help of professional hunting guides, he finally succeeded in collecting specimens for his innovative diorama of buffalo on the Montana plains. ${ }^{20}$ At this time, Hornaday estimated the wild buffalo population in Great Plains states at less than $100 .{ }^{21}$

The slaughter of the North American buffalo surely represents one of the saddest chapters in American environmental history. To many Americans at the time, the slaughter seemed wasteful and wrong as many newspaper editorials and letters to Congressmen attest, but still little was done to stop the slaughter. While several Great Plains states enacted legislation to limit and control the hunt, these laws were ineffective and unenforceable. The only serious piece of federal legislation was passed by both houses in 1874 only to be killed by a pocket veto by President Grant.

The destruction of the buffalo and the wanton slaughter of other big

\footnotetext{
${ }^{18}$ See Robinson (1995, p. 31).

${ }^{19}$ See Hanner (1981, p. 246).

${ }^{20}$ An updated version of Hornaday's diorama can be seen today by visiting the American Museum of Natural History in New York or via their website at www.amnh.org (search for bison and pronghorn diorama).

${ }^{21}$ In response to the rising scarcity several ranchers thought it worthwhile to capture and breed bison. Famed Texas Rancher Charles Goodnight obtained several buffalo from the panhandle that were remnants of the great Southern herd. These animals became of one five foundation herds in the U.S. from which almost all bison are descended. Other bison herds were collected and some of these became the foundation stock for the Yellowstone herd set up in the early 1890s.
} 
game across the west did however pay some dividend. The slaughter of the buffalo in particular was pivotal in the rise of the Conservation movement in the late 19th and early 20th century. Almost all of the important players in the Conservation movement experienced the slaughter first hand - Teddy Roosevelt, John James Audobon, John Muir and William Hornaday. ${ }^{22}$ The creation of the national park system in general, and the Yellowstone herd in particular, are a direct consequence of the revulsion many felt to the slaughter on the Great Plains. Because of these efforts, over 300,000 buffalo are alive today in reserves and commercial ranches across North America.

\subsection{Buffalo Biology}

Buffalo are enormous animals. Mature males are 10-12 feet in length, 6.5 feet in height, and weigh up to $2500 \mathrm{lbs}$. Female buffalo are proportionately smaller but still very large weighing up to 1500 lbs. They are also surprisingly agile given their size and weight: buffalo can broad jump over 15 feet, jump 6 foot high fences and run at a top speed of 40 m.p.h. for several miles. Buffalo have very poor eyesight, good hearing and a very acute sense of smell. Their natural predators are few: grizzly bears are an occasional predator, while wolves are a threat to the herd's sick, old and the very young.

Buffalo are perhaps more fecund than cattle with rates of net fertility in the range of .15-.25. Breeding can occur at anytime of the year but peak season is from early June to the fall. In a well nourished herd, 85 to $90 \%$ of the mature cows will bear a calf in the spring. Not surprisingly, given their original abundance, buffalo make very efficient use of prairie grasses. While they have four stomachs like cattle and other bovines, their slower metabolism withdraws more energy from the same grass. ${ }^{23}$

These features of buffalo biology determined much of their history. Given their size, dexterity and speed, killing a buffalo using stone tools is not a simple task. Even though natives used buffalo jumps, surrounds, and pens to kill buffalo en masse, subsistence hunting could only have a small impact

\footnotetext{
${ }^{22}$ The badge worn by National Park Service employees features a buffalo bull modeled after the bull killed and mounted by Hornaday in his buffalo diorama. Hornady became the first director of the Bronx Zoo, and was the first head of the American Bison Society. The buffalo bull imortalized on the buffalo nickel was modeled after a large bull in the live buffalo collection created by Hornaday at the Bronx Zoo. There are numerous Hornaday awards given by Conservation groups all across America.

${ }^{23}$ See Lott (2002).
} 
on a population with such a robust growth rate. Before European contact, buffalo numbers were kept in check by natural and not man made limits. Given their 3 million square miles of range, huge buffalo herds result.

Two other features of buffalo biology play an important role in their history. Buffalo divide into sex segregated herds for much of the year. Bull herds and cow-calf herds are the predominate forms, although for some time of the year yearlings also separate. Only during the spring and summer (May through August depending on location) do these herds meet and congregate on the open plains. During the rest of the year the herds divide up into much smaller groups of 60 to 100 that seek out small river valleys and other sheltered locations where vegetation is more plentiful and winter storms less severe. As a consequence, the time to efficiently kill large numbers of buffalo is in the summer months when they are concentrated on the open plains. ${ }^{24}$

While hunting in winter meant facing difficult winter conditions, finding only small groups of buffalo, and obtaining less meat from the leaner buffalo, it is during winter that the buffalo's thick coat reaches its pinnacle. Starting in early fall, buffalo regrow their winter coat which they then subsequently shed in the spring. Winter coats are dark and thick and make handsome buffalo robes when tanned; summer coats are thin, scruffy and not suitable for the robe market. Buffalo hides suitable for "buffalo robes" were taken only during three months of the winter, and some buffalo on the southernmost ranges never sported a robe worth taking.

These last two features of buffalo biology played a critical role in limiting the market for buffalo products. When buffalo were easy to kill, their robes were virtually worthless; when they were difficult to kill, their robes were valuable. Nature inadvertently endowed the buffalo with a defense against over exploitation.

European contact and the conversion of lands east of the Mississippi to agriculture, changed the buffalo's limiting factor from nature to man. Hunting increased and was spurred on by both a domestic and world demand for buffalo robes, but this demand could not exceed a supply constrained by the natural rhythms of buffalo biology and the supply bottleneck created by a laborious native tanning process. Even after the civil war, the Great Plains were virtually deserted, and this left the buffalo much of the most produc-

\footnotetext{
${ }^{24}$ The herds could be immense with many reported herds containing 50 to 100 thousand animals. Colonel Irving Dodge in 1871 came across a herd along the Arkansas river near Fort Larned that was subsequently estimated (by Horndady see $(1889$, p.390) to contain 4 million buffalo. Dodge's original account is contained in Dodge (1877, p.120).
} 
tive mid-grass prairie in Kansas, Oklahoma and northern Texas. Absent an innovation that made full time buffalo hunting possible, the buffalo population would have trended slowly downward for decades as it had east of the Mississippi. History however was not so kind to the buffalo.

\section{The Model}

I develop a simple dynamic model where agents hunt for buffalo or work in the outside good sector. Buffalo hunters were typically young single men with relatively low opportunity costs and limited skills. Many were civil war veterans or new immigrants who had moved west seeking their fortune. Their alternative occupations as laborers in frontier towns, cow punchers, soldiers, or railroad crew workers rarely paid very well. ${ }^{25}$ To someone with limited skills, except perhaps with a rifle, buffalo hunting was a potential road to riches.

Not surprisingly, entry and exit from buffalo hunting was common. Indeed the explosion of activity at the start of hide hunting in the early 1870s was nothing less than spectacular. Historic accounts describe an industry of hunters that grew from a small cottage industry that supplied nearby towns and railroad crews with meat to an army of thousands that lined rivers and closed off all avenues of escape. Since the entry and exit margin is so important to capture, I will determine the number of active hunters endogenously while representing the pool of potential hunters by a continuum of agents with mass $\mathrm{N}$.

\subsection{Individual Decisions}

Potential buffalo hunters were distributed throughout the Great Plains, but concentrated in small towns and forts near known buffalo ranges. I assume potential hunters differ in their hunting skill but are equally productive working in any one of the number of low-skilled occupations represented by the outside good sector. Differences in hunting skill are important in determin-

\footnotetext{
${ }^{25}$ Teddy Roosevelt described them as "absolutely shiftless and improvident; they had no settled habits; they were inured to peril and hardship, but entirely unaccustomed to steady work; and so they afforded just the materials which to make the bolder and more desperate kinds of criminals", Roosevelt (1889, p.13). More detailed, and less harsh, personal accounts are compiled in Gilbert et al. (2003).
} 
ing a margin for entry and exit, but they also reflect the very real fact that some hunters are simply better than others.

When faced with the opportunity to hunt, a potential hunter has two choices: ignore the herd and remain in the outside good sector; or join in the hunt. If an agent hunts, they earn the value of harvest $p h$ over the next increment of time $d t$, where $h$ is the quantity of buffalo killed and $p$ the price of buffalo products obtained from a kill. If the hunter remains in the outside good sector they earn the value of their marginal product given by their wage $w$. All prices and costs are measured in terms of the outside good which we take as the numeraire; therefore $p$ is the relative price of buffalo products.

Let $S(t)$ denote the size of the buffalo herd in physical units at time $t$. Then assuming a hunter's productivity is proportional to the size of the herd, a hunter with skill $\alpha$ earns $p h=p \alpha S(t)$ per unit time. ${ }^{26}$ To allow for skill differences across hunters let $\alpha \in[0, \bar{\alpha}]$ with $F(\alpha)$ being the distribution function of hunting skill. ${ }^{27}$ With these assumptions in place the marginal hunter, if one exists, is defined by his/her productivity, $\alpha^{*}$, such that:

$$
p \alpha^{*} S=w
$$

where the dependence of $S$ on time has been suppressed. Assuming free entry and exit, we obtain a simple division of agents at any point in time. Any potential hunter with skill $\alpha \geq \alpha^{*}$ hunts; the remainder work in the outside good sector. ${ }^{28}$

\subsection{Resource constraints}

Two aggregate constraints close the model. The first is simply an adding up constraint. Agents hunting plus those in the outside good sector must add up to the entire population. If the mass of potential hunters is $N$, the total

\footnotetext{
${ }^{26}$ Setting $p h=p \alpha \Psi(S(t))$ with $\Psi(0)=0, \Psi^{\prime}>0$, and $\Psi^{\prime \prime}<0$ makes little difference to the results.

${ }^{27}$ Some productivity figures are available in the literature; for example, W.S. Glenn reports that a remarkable hunter can kill 75-100 per day; an average hunter 50; a common hunter 25, and others hardly enough to run a camp. See Strickland (1949).

${ }^{28}$ There were fixed and sunk set up costs in hunting which I am ignoring here for simplicity. An earlier version of the model allowed hunters to make a truly dynamic investment decision when they choose to hunt. The more complicated model yielded predictions very close to those given by this simpler set up. Occam's razor, and seminar participants, pushed me to adopt the simpler specification.
} 
number of active hunters is $N\left[1-F\left(\alpha^{*}\right)\right]$, while $N F\left(\alpha^{*}\right)$ work in the outside good sector. Since $\alpha^{*}>0$ (recall 1), the outside good is always produced. Assuming constant returns in the outside goods sector, and choosing units such that output equals labor input, $w=1$ at all times.

The second constraint links the buffalo kill to the evolution of herd size. Define $K\left(\alpha^{*}, S\right)$, as the number of buffalo killed per unit time when the herd is of size $S$, and agents with productivity no less than $\alpha^{*}$ are engaged in buffalo hunting; that is:

$$
K\left(\alpha^{*}, S\right)=S N \int_{\alpha^{*}}^{\bar{\alpha}} \alpha f(\alpha) d \alpha
$$

where the density of buffalo hunters with productivity $\alpha$ is $F^{\prime}(\alpha)=f(\alpha)$, their mass is $N f(\alpha)$, and their productivity in hunting is $\alpha S$. I refer to 2 as the kill function. Since the marginal hunter is determined at every moment in time by the prevailing price and herd size using 1 , we obtain with a slight abuse of notation, $K\left(\alpha^{*}(p, S), S\right) \equiv K(p, S) . \quad K(p, S)$ is the number of buffalo killed per unit time when the herd is of size $S$, and the price of buffalo products is $p$.

To determine how the kill responds to herd size, differentiate 2 to obtain:

$$
\frac{d K(p, S)}{d S}=N \int_{\alpha^{*}}^{\bar{\alpha}} \alpha f(\alpha) d \alpha-N S \alpha^{*} f\left(\alpha^{*}\right) \frac{d \alpha^{*}}{d S}>0
$$

where $\frac{d \alpha^{*}}{d S}<0$, from 1 . When the herd grows in size two things happen: the productivity of inframarginal hunters rises, and new hunters enter as hunting now generates rents for even the low skilled. The combination of increased entry and greater productivity for those already present means buffalo kills rise with herd size.

When the herd becomes small just the opposite occurs: agents exit and average productivity drops. As a result, there will exist a herd so small that only the most skilled find it worthwhile to hunt. Since the highest productivity hunters have productivity, $\bar{\alpha}$, the smallest herd size ever hunted, $S_{s}$ must satisfy:

$$
\bar{\alpha}=w / p S_{s}
$$

When $p$ is sufficiently high we have $S_{s} \leq C$ where $C$ is the carrying capacity of the Great Plains. 
Rational agents will never hunt a herd if $S<S_{s}$. Taking this complication into account, the kill function becomes:

$$
\begin{aligned}
K(p, S)=0 & \text { if } S \leq S_{s} \\
K(p, S)=N S \int_{\alpha^{*}}^{\bar{\alpha}} \alpha f(\alpha) d \alpha & \text { if } S_{s}<S \leq C
\end{aligned}
$$

To determine the dynamics of herd size I combine the kill function with an assumption on how the herd grows over time. For simplicity, I assume herd size grows in accordance with a standard compensatory growth function drawn from resource economics. Biological growth, $G(S)$, is assumed to be a positive (strictly) concave function of herd size. Natural growth is zero when the buffalo are gone $G(0)=0$, and zero when the buffalo reach the carrying capacity of the Great Plains, $G(C)=0$.

The evolution of herd size can now be written as:

$$
\dot{S}=G(S)-K(p, S)
$$

With no hunting at all, $K(p, S)=0$ and the buffalo population would return to its carrying capacity $C$. With active hunting the herd will be smaller, and could in principle be driven to zero depending on parameter values. Solving 6 (subject to an initial condition) generates a time profile for the buffalo herd, the kill, hunter numbers, and the output of the outside good.

\subsection{Steady State Solution}

A typical interior steady state is shown in Figure 1. The growth function $G(S)$ starts at $S=0$, rises and then returns to zero growth when the herd reaches its carrying capacity at $C$. A typical kill function is also shown. The kill is zero for small herd sizes, but at $S_{s}(p)$ hunting begins and then grows in intensity. The kill function is not necessarily convex (as shown), but even when it is not, under mild conditions, there is a unique interior solution .

Proposition 1. Assume: $C>S_{s}$, then there exists

i) a unique interior steady state herd size $S^{*} \in\left[S_{s}, C\right]$;

ii) a unique marginal hunter $\alpha^{*}\left(p, S^{*}\right) \in(0, \bar{\alpha})$; and,

iii) a unique division of agents across activities.

Proof: See Appendix A. 


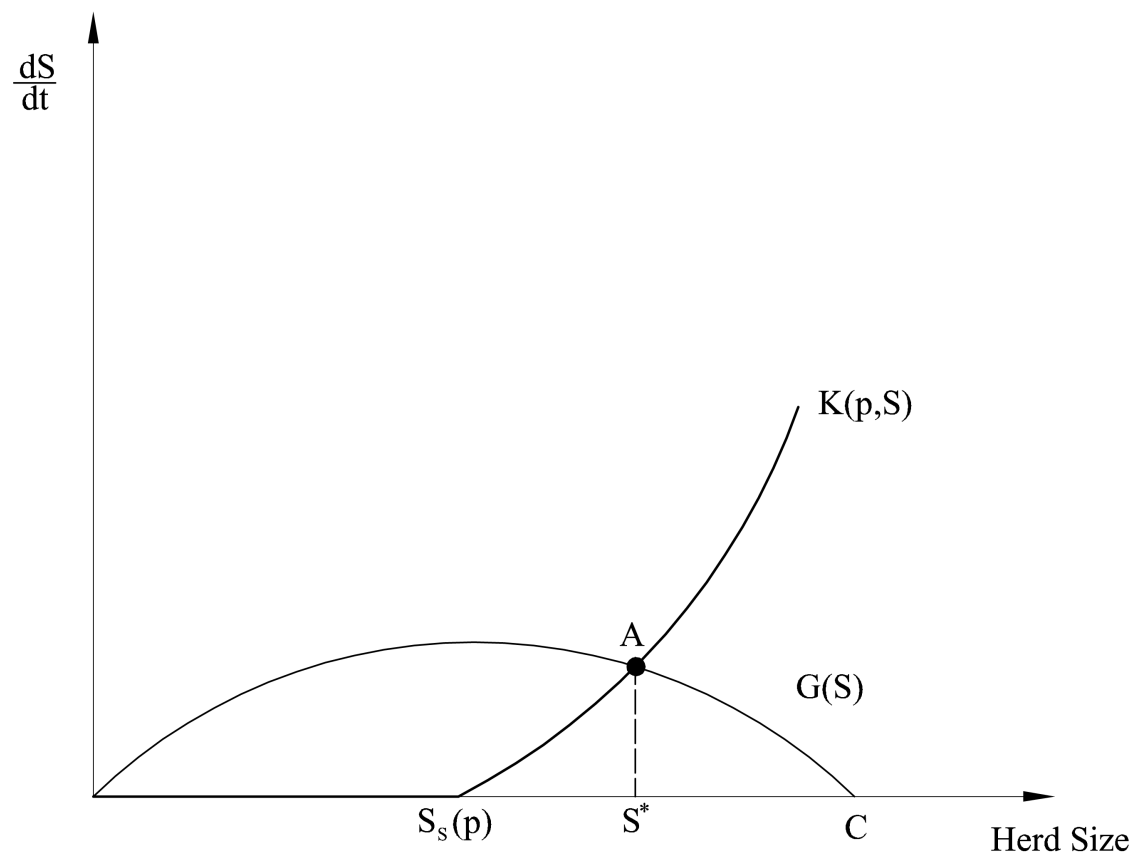

Figure 1

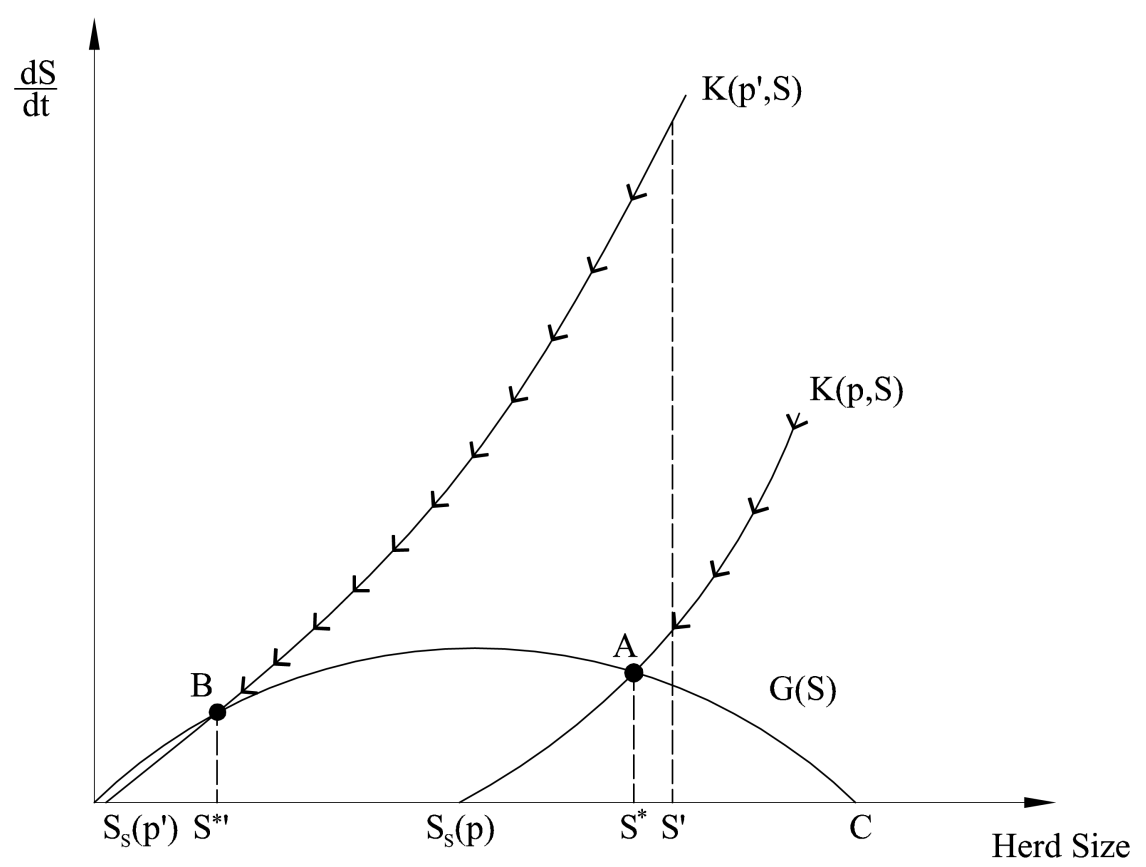

Figure 2 
Uniqueness and existence are guaranteed by very weak conditions. An interior steady state can only exist if buffalo hunting is profitable for some agent at some herd size. If the carrying capacity is greater than the smallest profitable herd size we have $C>S_{s}$, and $p \bar{\alpha} C>w$ from 4 . This implies buffalo hunting can provide rents to the most productive hunters when the herd is close to carrying capacity. The steady state also determines the productivity of the marginal hunter $\alpha^{*}=m\left(p, S^{*}\right)$, the number of hunters $N\left[1-F\left(\alpha^{*}\right)\right]$, their aggregate kill $K\left(p, S^{*}\right)$, and the number of agents in the outside good sector $N F\left(\alpha^{*}\right)$.

It is clear from Figure 1 that the interior steady state is globally stable. Starting from any positive stock level $S>0$, convergence to the steady state is monotonic. If the initial stock is very low, no hunting occurs, the buffalo herd grows in response and this brings about the introduction of hunting and a reduced rate of herd growth. Starting with a very large herd size, the kill exceeds natural growth and herd size falls. For future purposes we note:

Proposition 2. When a unique interior steady state exists, it is globally stable. Starting from any positive buffalo herd size $S>0$, convergence to the steady state is monotonic.

Proof: See Appendix A.

\subsection{Slaughter on the Great Plains}

For the most part I focus on the destruction of the Southern Herd as this was the immediate result of the tanning innovation and signalled the introduction of the hide market.

The introduction of buffalo hide tanning was a positive price shock for buffalo products. Before the tanning innovation, a buffalo hunter would kill for some combination of the animal's meat (including the tongue) and robe. A buffalo kill was a joint product yielding a fixed ratio of several outputs each with its own price. Once the tanning of buffalo hides was possible, the composition of these outputs changed to include hides. Historic accounts are clear that the introduction of the hide market vastly increased the return to buffalo hunting so that most meat was left to rot on the plains, and killing took place in regions where robes were of poor quality (much of the southern U.S.) and at times of the year when robes were virtually worthless. All of this implies that we should model the impact of the tanning innovation as 
raising the effective price for a buffalo kill from $p$ to $p^{\prime}{ }^{29}$

The historical account is also fairly clear that before the tanning innovation, buffalo numbers were falling although slowly. Hunting pressure and eventually habitat destruction would have led buffalo numbers to fall as they had east of the Mississippi, but the strength of these two forces was weak in the 1860 s. To capture this feature of the pre-1870 period, I assume the economy was operating somewhere along its transition path to an initial steady state when the price shock hit.

\subsubsection{Destroying the Southern Herd}

In Figure 2 I plot the growth function and two kill functions $K(p, S)$ and $K\left(p^{\prime}, S\right)$. Prior to 1870 the value of a buffalo kill was given by $p$, and hence the kill function $K(p, S)$ intersects the horizontal axis at $S_{s}(p)$; the steady state corresponding to this price is given by $A$. I assume the economy was moving along $K(p, S)$ towards the steady state at $A$ from the right. Buffalo numbers were falling, but slowly. Without the tanning innovation, the economy would have moved closer to $A$ over time with falling buffalo numbers, lower rents and fewer hunters. An important feature of the model is that with small rents in buffalo hunting prior to the innovation, only a small number of agents are active in hunting even though rents are positive.

The tanning innovation changed all that. When the price shock hit, the kill function shifts to $K\left(p^{\prime}, S\right)$, dramatically raising the kill. There is a flood of new entry as the hunting skill needed to justify entry drops discretely from $\alpha^{*}\left(p, S^{\prime}\right)$, to $\alpha^{*}\left(p^{\prime}, S^{\prime}\right)$. The boom in new entrants raises the rate of buffalo kill abruptly and the slaughter begins. As the buffalo boom unwinds the economy moves along $K\left(p^{\prime}, S\right)$. The number of buffalo hunters falls, average productivity falls, and the killings fall. Over time, the economy moves towards its new steady state at $B$. Summarizing:

Proposition 3. An unexpected permanent price shock:

i) raises the number of buffalo hunters and kill on impact;

ii) leads to exit and falling buffalo kills along the transition path; and,

iii) lowers the steady state buffalo herd.

Proof: See Appendix A.

\footnotetext{
${ }^{29}$ Modeling the tanning innovation as an increase in harvesting productivity $\alpha$ would not be correct. Tanning did not increase the technical efficiency of buffalo hunting, it just raised the economic returns to it.
} 
The transition path exhibits overshooting in the number of hide hunters for a simple reason: rents cannot last. Relatively high cost hunters enter today knowing that this will be a short-lived game, and as the herd diminishes, more and more hunters retire from buffalo hunting. Only those with very low hunting costs remain in the industry. The new steady state features more hunters chasing fewer but more valuable buffalo, with the marginal hunter again receiving no rents at all.

It is apparent from the figure that both the buffalo herd and the number of buffalo hunters adjusts when prices rise. Surprisingly, the steady state buffalo kill may rise or fall in response. The kill rises if the buffalo herd exceeded $C / 2$ prior to the price shock and the price shock itself was marginal. In all other cases it falls. Since Hornaday estimated that less than 100 buffalo were left in the wild by the late 1880 s while $C$ is perhaps 25 million, the $S^{*}<C / 2$ case is most relevant to our discussion. In this case, the aggregate kill, in steady state, falls with the price shock.

\subsubsection{Destroying the Northern Herd}

The history of the Northern Herd is slightly more complicated. By the mid 1870s, the innovation and the advent of the flint hide market were all in place, but the boom in northern hunting did not occur until 1881. The reason for the delay seems to be the hostile Sioux nation. ${ }^{30}$ The Sioux nation was the last significant Indian threat in the U.S., and after the defeat of Custer in 1876 the U.S. Army began an unrelenting campaign to eliminate this threat. It was only in the early 1880s that the remaining Sioux were either killed or settled peacefully on reservations. The legendary Crazy Horse surrendered in 1877, while the chief who defeated Custer - Sitting Bull - surrendered in 1881. During most of this period, hide hunting in the north was very dangerous. At virtually the same time, the Northern Pacific railroad made its way into Montana. This surely lowered transport costs and raised the price buffalo hunters could obtain for a kill.

In terms of our model, the change in hunter safety could be taken as an exogenous shift rightward in the distribution $F(\alpha)$. The new railroad would represent a small price shock, since transportation along the Missouri by steam ship was already an available and well used transportation

\footnotetext{
${ }^{30}$ At this time, the Sioux, Northern Cheyenne and Northern Arapho were not yet part of the reservation system. They were led by the most important non-treaty chief: Sitting Bull.
} 
option. These two shocks work in much the same way and generate the same dynamics as the initial tanning innovation. Therefore, while it is unclear what determined the exact timing of the Northern Herd's slaughter, the model's assumptions combine to deliver excessive hunting, overshooting, and a punctuated buffalo slaughter. These are important features of the northern slaughter.

\subsection{The Autarky Counterfactual}

The model does a reasonable job in replicating the broad features of what we know about the hide hunt. The tanning innovation created a great deal of entry that was subsequently followed by exit. Early hunters earned large rents as they often left to buy ranches, saloons, or set up stores in frontier towns. $^{31}$ Late entrants and the stragglers seemed to do less well. Although the model is successful in replicating the historical record, it does rely on a fixed price for buffalo products. As such it implies that large exports of buffalo hides must have occurred over this period, and this is yet to be proven.

An alternative hypothesis is that tanneries in the eastern U.S. provided the demand for hides, and in many accounts a strong U.S. domestic demand for leather is implicated in the slaughter. Evidence for this connection is however weak. Apart from the price quotes for bison sole leather in the N.Y. market for 1878 and 1879 (which I discovered), and some mention of eastern tanneries in Hornaday, I have been unable to find any direct evidence in the form of shipments, tanned hide output, etc. ${ }^{32}$ Census figures from this period argue against the large scale use of buffalo in tanning, since the total measured input of raw hides into U.S. tanning and currying, falls short of the number of cow hides imported plus the (estimated) domestic slaughter. This leaves no room at all for the millions of buffalo hides to be used in the U.S. tanning industry. These census figures are only for two years, 1870 and 1880, and we have only estimates for the domestic cow slaughter. Therefore, the data is not definitive on this issue, and it is useful to ask if the market

\footnotetext{
${ }^{31}$ See Gard (1955), the personal accounts reported in Gilbert et al. (2003), and the highly entertaining first person account of Frank Mayer "the last living buffalo hunter" in Mayer and Roth (1958).

${ }^{32}$ There is an often repeated story of 57 hides sent by Wright Moar to his brother in N.Y. city who then sold them to Pennsylvannia tanners thus starting the U.S. domestic market.
} 
had been purely domestic what would have happened to the buffalo? Is a fixed price and robust export market necessary to explain the slaughter on the plains or is it merely sufficient?

To examine these questions I develop an autarky counterfactual by introducing domestic market clearing. Since the elasticity of demand ought to be critical in determining the price response, I adopt a constant elasticity of demand formulation where tastes over the two goods: hides and manufactures (the outside good) are homothetic. I again solve for the model's steady state and examine the response of hide hunters to a shock that raises the value of a buffalo kill (by making their hides useful leather products).

I start by solving for the market clearing price, and then link the equilibrium price to the prevailing herd size and solve for the marginal hunter

$\alpha^{*}(p, S)$. This initial step is necessary because the dynamics of entry and exit are now more complicated as price adjustment alters the entry decision, while entry affects price adjustment.

\subsubsection{Market Clearing}

The relative supply of hides to manufactures at any point in time is given by the buffalo kill divided by output from the outside good sector.

$$
\left(\frac{H}{M}\right)^{S}=\frac{K(p, S)}{F\left(\alpha^{*}(p, S)\right) N}=R S(p, S)
$$

where $\alpha^{*}(p, S)$ is implicitly defined in $1 .^{33}$

The relative supply of hides to manufactures is increasing in $p$ because more agents enter buffalo hunting and this generates larger kills while reducing labor in the outside good sector. An increase in herd size has a similar effect.

Relative demand is independent of income and can be written as:

$$
\left(\frac{H}{M}\right)^{D}=\varphi(p)=\beta[p]^{-\sigma}
$$

where $\beta>0$ is a demand shifter. Equating supply and demand solves for the equilibrium price $p^{e}$ as a function of herd size and other parameters.

$$
\beta\left[p^{e}\right]^{-\sigma}=R S\left(p^{e}, S\right)
$$

\footnotetext{
${ }^{33} R S(p, S)=0$ for $p \leq w / \bar{\alpha} S$, and is positive otherwise; i.e. there exists a minimum price needed to generate hunting at any stock.
} 
Differentiate 9 with respect to the herd size to find, after some rearrangement,

$$
\frac{d p^{e}}{d S} \frac{S}{p^{e}}=-\left[\frac{1+\varepsilon_{r s, p}}{\sigma+\varepsilon_{r s, p}}\right]<0
$$

where $\varepsilon_{r s, p}>0$ is the elasticity of the relative supply curve with respect to $p .{ }^{34}$ With this result in hand it is now possible to prove an important intermediate result:

Lemma 1. Buffalo hunter numbers rise, stay constant, or fall with an increase in the buffalo herd, $S$, as $\sigma$ is greater than, equal to, or less than one in magnitude.

Proof: See Appendix A.

The intuition for Lemma 1 is simple and familiar. Assume the number of hunters in the field is fixed, and consider an increase in herd size. Relative supply shifts outwards, lowers prices, and increases the quantity of buffalo killed. When demand is unitary elastic, the price decline is exactly matched by the increase in herd size (evaluate 10 at $\sigma=1$ ). Therefore, the marginal hunter is indifferent to exit as before (recall 1), and the number of hunters in the field is unaffected by herd size.

When demand is inelastic, the quantity impact of the change in $S$ is swamped by the resulting price reduction. The marginal hunter must be more able than before, $\alpha^{*}$ rises, and exit occurs. When demand is elastic a larger herd size lowers prices only slightly and this tempts new - relatively unproductive - entrants to join in the hunt.

Not surprisingly, Lemma 1 has an important bearing on the model's predictions. Using lemma 1 we know that when $\sigma$ is equal to one, $\alpha^{*}$ is independent of herd size..$^{35}$ The kill function is a straight line through the origin. When $\sigma$ is greater than one, $\frac{d \alpha^{*}}{d S}<0$, and the kill function is positively sloped as it was before. In both of these cases we can employ the techniques used in the proof of Proposition 1 to show the autarky steady state is also unique. But when $\sigma$ is less than one we cannot rule out a negatively sloped kill function and multiple steady state equilibria. Despite these complications, we can proceed. To do so we need another intermediate result.

\footnotetext{
${ }^{34}$ See the proof to Lemma 1 for a derivation.

${ }^{35}$ In this case the marginal hunter is still fully determined. $\alpha^{*}$ adjusts so that the share of aggregate income spent on buffalo products is equal to the constant Cobb-Douglas share.
} 
Lemma 2. A positive demand shock $d \beta>0$ shifts the kill function upwards and raises the domestic price for any given herd size, $S$.

Proof: See Appendix A.

Lemma 2 tells us that an autarky demand shock created by the advent of tanning drives the price of flint hides upwards and raises the kill for any herd size. Using Lemma 1 and 2 we can now prove.

Proposition 4. Starting from any stable steady state, an unexpected and permanent demand shock, $d \beta>0$ :

i) lowers the steady state buffalo herd, $S$;

ii) raises buffalo hunter numbers on impact;

iii) leads to falling (constant, rising) hunter numbers along the transition path if $\sigma$ is greater than (equal to, or less than) one in magnitude.

Proof: See Appendix A.

Proposition 4 tells us that the autarky counterfactual can only deliver a boom and bust pattern in hide hunting when demand is sufficiently elastic. When the innovation arrives the demand for buffalo shifts upwards along a given supply curve. The surge of new entrants raises the kill on impact. Over time the herd shrinks, the supply curve shifts back, prices rise and hunter numbers adjust to the combination of changing prices and a shrinking herd size. When $\sigma$ is greater than one the transition period exhibits excessive initial entry and then exit along the path to the new steady state. When demand is unitary elastic, the initial surge of entry is followed by zero exit, and when demand is inelastic the initial entry is followed by further entry over time. In all three cases, hide prices rise as the buffalo slaughter continues.

The autarky counterfactual is important in demonstrating that the pattern of boom and bust experienced on the Great Plains is consistent with the slaughter being fueled by the tanning innovation together with an elastic domestic demand for buffalo hides. While several authors have argued that the U.S. had a large domestic demand for industrial leather at the time and this demand was pivotal in the slaughter, these accounts become less persuasive in the face of evidence that the innovation was foreign made, that hide prices did not rise over the period, and that buffalo hide exports represent a significant portion of the slaughter. 


\section{Empirical evidence}

A natural consequence of the rapid and violent slaughter of the buffalo is that records of the number of buffalo killed are non-existent. Existing academic work instead relies on a variety of sources to quantify the extent and timing of the kill. One common estimate of the slaughter's magnitude starts with estimates of an initial stock of buffalo using carrying capacity estimates of the Great Plains and then finishes with the observation that by the late 1880s the number in the wild was estimated at less than 100 . The difference say, between a mid century estimated population of 15 million, and the final figure of 100 represents the slaughter. While this procedure is valuable in setting rough parameters for a more detailed accounting, it says little about the pace of the slaughter, its geographic location, or its ultimate cause.

An alternative approach is to employ data that is available on shipments of hides by the railroads operating in buffalo country and then amend these to take account for wastage prior to delivery. In the mid-1870s, Colonel Richard Irving Dodge contacted the three major railroads serving the main buffalo hunting areas. Dodge contacted the Atchison, Topeka and Santa Fe, the Kansas Pacific and the Union Pacific railroads asking for data on the shipments of buffalo products. Of these three, only the Atchison, Topeka and Santa Fe (ATS) responded and provided figures for hides shipped in 1872,1873 and $1874 . .^{36}$ It is important to note that these three numbers (one for each year) for hides shipped are the only data available on the number of buffalo killed in the Southern Herd. Additional numbers are often presented in secondary sources, but these additional data come from either extrapolations, estimated wastage adjustments, or estimates of kills by natives and settlers.

Dodge makes two adjustments to the shipping numbers. First, to correct for the non-response of the other two major railroads, Dodge multiplied ATS numbers by three since he viewed the other two as equally likely to have shipped as many hides. Second, to account for the loss of killed or injured animals on the ground or the ruining of hides in skinning or transport, Dodge

\footnotetext{
${ }^{36}$ The lack of enthusiasm in reporting shipments is not surprising. Most of the states in the Great Plains were considering or had put in place restrictions on buffalo hunting; in addition, sentiment out East was moving against the slaughter. The railroads however needed cartage business and would not have wanted the bad publicity - and perhaps federal legislation - such revelations could have brought. A good account of the history of restrictions on buffalo hunting can be found in Hanner (1981).
} 
inflates individual year shipment data by a factor representing the ratio of buffalo killed to buffalo hides shipped. In the first years of the slaughter, waste was very high and Dodge estimates that in 1871 every hide shipped represents five dead buffalo. In 1872 this falls to three, and by 1873 one shipped hide represents two dead buffalo; finally in 1874 there was very little waste with one shipped hide representing one and a quarter dead buffalo. By these methods, Dodge arrives at the estimate of a little over 3 million buffalo killed from 1872-1874 on the Southern plains. Hornaday (1889) adds to Dodge's estimate a figure representing hunting by natives and settlers to arrive at an estimate of 3.7 million.

Estimates of the slaughter in the north are more tenuous. The northern shipping point was Fort Benton, located in northern Montana on the Missouri until the Northern Pacific Railroad hit Miles city. Koucky reports the number of hides shipped in the peak years of 1881 and 1882 at $270,000{ }^{37}$ Hornaday estimated that the kill off in the north must have been less than 1.5 million.

It is obvious from this account that very little is known with certainty about the magnitude and pace of the slaughter. Many observers lamented the sorry state of the plains at this time - the lines of putrid carcasses, the bone fields, and the large stack of hides at railroad stations. From these it is clear that a punctuated slaughter did occur, but its extent and exact timing are far less certain. Individual eye witness accounts add colorful description to more factual accounts, but are not of much use in distinguishing between a slaughter of say 3 million and one of 10 million.

To examine the potential role of international trade in the buffalo's demise it is of course natural to look at trade statistics, which until now, have apparently been ignored by researchers in this area. The benefit of trade statistics is that they often provide estimates of key physical and value flows when production data are known to be either incomplete or entirely absent. Governments have a strong incentive to record and meter the value and volume of materials entering and leaving their country since import and export taxes were a major source of revenue at the time. Accordingly, trade statistics often tell a story where production statistics alone cannot. The same appears to be true here, although with some caveats.

\footnotetext{
${ }^{37}$ Robinson (1995, p.140) however presents larger estimates. 250,000 from a dealer H.F. Douglas, another 180,000 from Custer county, and an additional 200,000 hauled on the Northern Pacific. I have been unable to find corroborating primary source evidence for these figures.
} 


\subsection{Buffalo Hide Exports}

I employ a multi-step procedure for identifying buffalo products in the international trade statistics. The procedure starts with the value of U.S. hide exports from 1865 to $1886 .^{38}$ To ensure that these are not re-exports from Canada, Mexico or other countries, I employ an exports from domestic production series.

I start by converting hide values into hide numbers by deflating value figures for exports, using estimates for hide prices. Hide prices are provided inconsistently in the series. I generate a complete price series by taking individual estimates provided in the data and filling in the gaps using a price index for leather and leather products provided by Warren and Pearson (1933). The constructed price series is then checked against other individual price quotes found in the literature. For example, an additional source for price data is the series of Annual Reports of the New York Chamber of Commerce which report prices for important items in the New York market. ${ }^{39}$ One item consistently reported over this period is sole leather (hemlock tanned). This price series can be used in place of the Warren and Pearson index as a check on our initial construction. There are also numerous price quotes given in historical documents that list prices paid to hunters for hides or robes. For example, Hornaday (1886, p.439-440) contains two hide price series from the 1880s. These prices are for hides inclusive of delivery to eastern markets: one gives prices ranging from $\$ 2.85$ in 1880 to $\$ 3.25$ in 1884 , while the other presents slightly higher prices at $\$ 3.50$ per hide throughout. As with other sources, this data is infrequent, varies with the location of the hunter, and the type of hide sold (bull, cow, calf, etc.). My own reading of diary accounts and other primary sources indicates common price quotes of $\$ 2.50$ for bull hides, $\$ 3.00$ for cow hides, and $\$ 1.00$ for calf hides. Prices appear to have fallen in the late 1870 s, and selling hides was difficult during the panic of 1873 . There are diary accounts of hunters selling hides for as little as $\$ .75$, but I have not found an account where a hide sold for more than $\$ 3.50$. Prices to hunters differ of course from the export values since they exclude the margins introduced by transportation and distribution. A

\footnotetext{
${ }^{38}$ See United States, Department of Treasury, Bureau of Statistics, Foreign Commerce and Navigation of the United States. Available online through Archive of Americana, U.S. Congressional Serial Set, 1817-1980, published by Readex, a division of Newsbank, inc. at http://infoweb.newsbank.com/.

${ }^{39}$ See State of New York Chamber of Commerce Annual Report for the years 1865-1890.
} 
rough approximation to the price hunters may have obtained is $60 \%$ of the export price.

In Table 1 below I present the series for hide prices developed using the Warren and Pearson price index and the alternative price series constructed using the price data drawn from Annual NY Chamber of Commerce reports. I have also included an estimate of the price a hunter may have received assuming transportation and distribution account for $40 \%$ of the delivered hide price. Since hides were worthless until 1871, the price-to-hunters series, starts at zero and then takes a jump upwards when the innovation hit.

Table 1 - Hide Prices $(\$ /$ Hide)

\begin{tabular}{cccccccc}
\hline \hline Year & W.P. & N.Y. & H.P. & Year & W.P. & N.Y. & H.P. \\
\hline 1866 & 4.56 & 4.74 & 0 & 1876 & 3.25 & 4.04 & 2.32 \\
1867 & 4.12 & 4.82 & 0 & 1877 & 3.40 & 3.42 & 2.43 \\
1868 & 3.93 & 4.43 & 0 & 1878 & 2.96 & 3.03 & 2.12 \\
1869 & 4.18 & 4.66 & 0 & 1879 & 3.12 & 4.51 & 2.23 \\
1870 & 3.99 & 4.51 & 0 & 1880 & 3.53 & 3.58 & 2.52 \\
1871 & 3.93 & 4.35 & 2.81 & 1881 & 3.40 & 3.42 & 2.43 \\
1872 & 4.06 & 4.35 & 2.90 & 1882 & 3.37 & 3.26 & 2.41 \\
1873 & 4.12 & 4.35 & 2.94 & 1883 & 3.34 & 3.34 & 2.38 \\
1874 & 3.99 & 4.20 & 2.85 & 1884 & 3.46 & 3.26 & 2.47 \\
1875 & 3.84 & 3.89 & 2.74 & 1885 & 3.28 & 3.58 & 2.34 \\
\hline
\end{tabular}

Notes: W.P. is hide prices found using the Warren and Pearson price index. N.Y. is hide prices found using data drawn from the Annual NY Chamber of Commerce reports. H.P. is the price-to-hunters series.

All of the constructed price series exhibit a slight downward trend over time. For example, the WP export price for hides was $\$ 3.93$ in 1871 the first year of the slaughter and $\$ 3.27$ in 1885 the last year. As shown, the NY hide price series differs very little from the main WP series, and all conclusions of the paper are unaffected by my choice of price index.

It is tempting of course to attribute the decline in hide prices to the additional supply created by the buffalo slaughter in the U.S. While in theory the slaughter could have an effect on world prices, as an empirical matter this is unlikely. The worldwide hide market was huge with yearly 
exports exceeding 100 million US dollars by $1880 .{ }^{40}$ The US share of this market is always small during the relevant period ranging from a high of $3 \%$ in 1860 to $.5 \%$ in both 1880 and 1890 . The U.S. was truly a small player in the world hide market.

Finally, while the two or three dollar jump in the value of a buffalo hide in 1871 seems relatively small to have such large effects, it should be remembered that a seasoned hunter could kill several thousand buffalo a season. Alternatively he could earn perhaps $50 \$ /$ month as a cattle hand. Clearly even at these relatively low hide prices, the rents to hide hunting were potentially very large.

By using the WP hide price series shown in Table 1, I can now deflate the value of hide exports to obtain a volume of hide export series. This series is shown in Figure 3 as the top most line with the large bulge centered on 1875. The line labelled Total Hides starts from a low of less than 100,000 in 1867, peaks at a little over 1.2 million in 1875 , then declines until it reaches 200,000 in 1880 . In the early 1880s, exports cycle back upwards only to fall again in 1886. I will argue that the large bulge of exports in the mid 1870s represents the destruction of the Southern Herd, while the smaller bulge in the early 1880s corresponds to the destruction of the Northern Herd.

To eliminate cattle hides from the volume of hide export series I construct a measure of cattle slaughtered in the U.S. using a well known economic model of the cattle cycle. The U.S. Agricultural Department publishes data from 1867 onwards on the number of cattle in the U.S. I have graphed this data in Figure 3 as Cattle. Since the number of cattle in the U.S. in 1867 is approximately 25 million and is over 55 million in the late 1880 s, the slowly rising line shown in the figure is graphed against the alternate right hand side axis which is measured in thousands of animals.

To move from cattle numbers to an estimate of the number of cattle hides exported several steps are required. ${ }^{41}$ First, I employ estimates drawn from Rosen, Scheinkman and Murphy, RSM, (1994) to generate an implied breeding stock from the overall cattle numbers. This step is necessary because not all cows are fertile, and not all cattle are cows. Using the implied breeding stock I then employ RSM's empirical estimates to generate an implied yearly slaughter. RSM develop a dynamic forward looking model of cattle

\footnotetext{
${ }^{40}$ For information on the magnitude of the world hide market see John R. Hanson, Trade in Transition: Exports from the Third World, 1840-1900, data sets are available online at http://eh.net/databases/developing.

${ }^{41}$ See appendix B for further details.
} 
Figure 3

The Construction of Buffalo Hide Exports

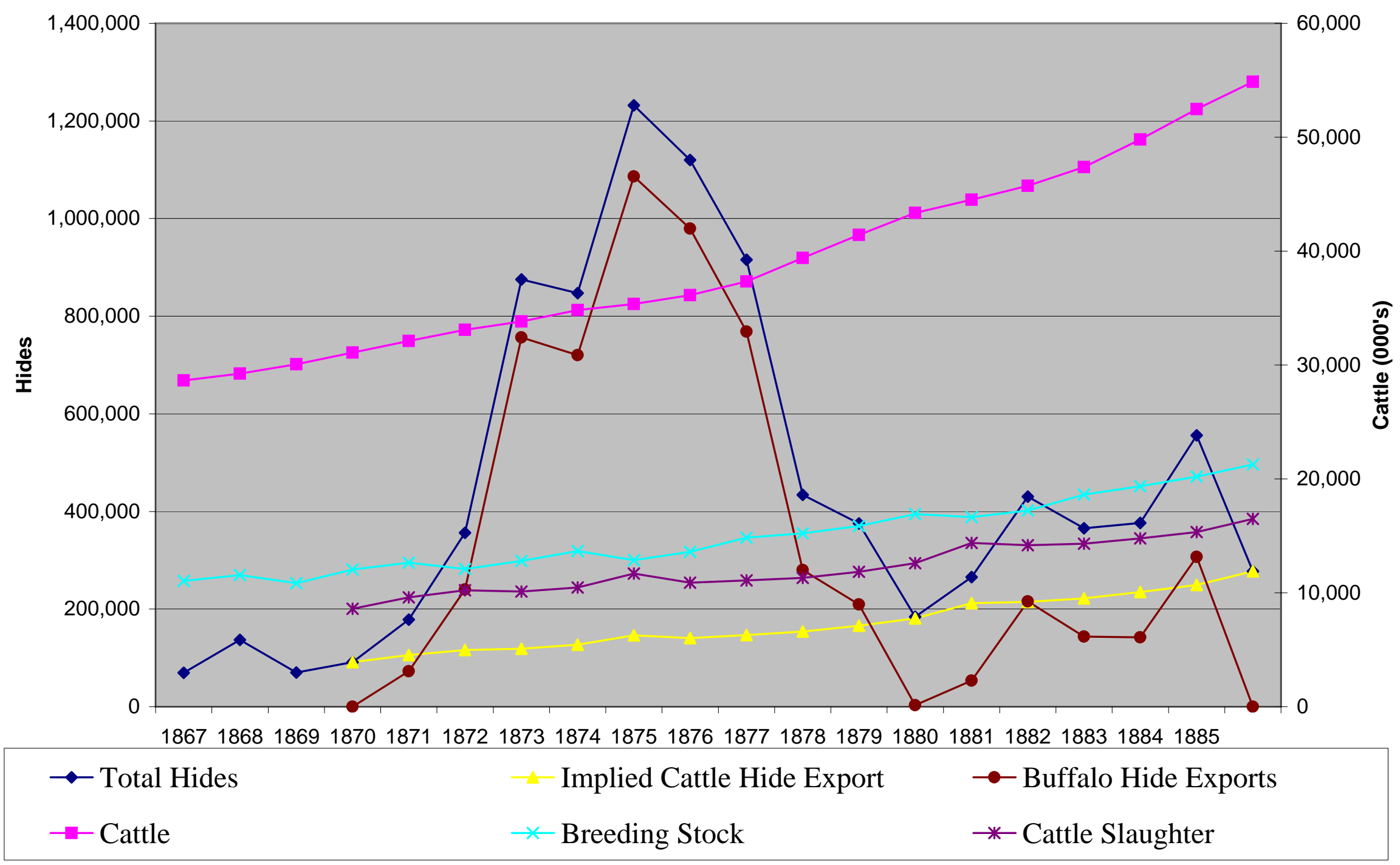


supply to study the cattle cycle in the U.S. and estimate their model on data starting in 1867. By employing their estimates I have calculated both the underlying breeding stock and the slaughter coming from the stock. The implied breeding stock and slaughter numbers are shown in Figure 3 and given their magnitudes both are graphed against the right hand side axis.

The final step in the identification of buffalo hides in exports uses additional data from historical sources and makes one further assumption. Historical sources all agree that prior to 1870, there was no market in buffalo hides. Up to this point in time, buffalo was hunted for its robe, its meat or killed for amusement. Without knowledge of how to tan a buffalo hide, the hide market was non-existent. This implies that in 1870 U.S. exports of hides could only be those of cattle. Under this assumption, I find that only $1 \%$ of the hides from slaughtered cattle are being exported in 1870 . Similarly, historical accounts indicate that hunting on the northern plains stopped sometime during the 1883-84 season; shipment of hides down the Missouri by steamboat or via the Northern Pacific by rail may have ended sometime later, and exports later still because of potential inventory effects. Accordingly, I have assumed that in 1886, the export of hides must again represent only cattle. By 1886, I now find that $1.7 \%$ of the hides from slaughtered cattle are exported. Using these two points as anchors, I then use a linear interpolation for the years in between. Doing so generates the light colored line representing an estimate of that part of the existing U.S. cattle slaughter that is exported. Subtracting the implied cattle hides from the overall hide export numbers yields our estimate for the number of buffalo hides exported from 1870 to 1886.

\subsection{Variation over time and regions}

The method of data construction is fairly lengthy and detailed. Were it not for the absolute paucity of other data on the number of buffalo killed or exported, and the existence of other confirming evidence that I shall now present, there would be little to suggest its acceptance. The series as constructed however has several desirable characteristics that argue in its favor.

First, note that by construction the series reaches zero in 1870 and 1886 (the two "identification points"), but also exhibits a severe dip in hide exports in $1880 .{ }^{42} 1879$ was the last year of the Southern hunt; and 1881 the first

\footnotetext{
${ }^{42}$ It is also worthwhile to note that even the unadjusted export series (with cattle hides
} 
significant year of the Northern hide hunt. It is therefore striking that our constructed series exhibits a pause as hunters moved from south to north.

Further confirmation comes from other aspects of the series. Using the series I calculate the implied number of buffalo hides exported during the entire 1871-1886 period. It sums to almost 6 million exported hides. Of the 6 million hides exported, 5 million hides come from what I am calling the $1870 \mathrm{~s}$ destruction of the Southern Herd, and only 1 million from the destruction of the Northern Herd. This is consistent with the accounts of Hornaday and many others indicating the Southern Herd was much larger than the Northern. For example, Hornaday estimates a northern kill of only 1.5 million whereas Figure 1 generates a total close to 1 million. Therefore the series generates a distribution across geographic region that roughly matches the historical account.

The total of 5 million killed in the south is however higher than that given in the estimates of Hornaday and Dodge, but both of these authors severely downplayed the extent of the Southern Herd destruction that occurred post 1874. As shown by the series in Figure 3, while exports peaked in 1875 there was still substantial hide exports well into the late 1870s. My own reading of the historical accounts of buffalo hunters (not available to either Hornaday or Dodge) indicates that hide hunting of significant magnitude did occur post 1874. For example, Dodge reports that in the "last year" of the Southern slaughter, 1874, the number of hides shipped by rail was only 126 thousand falling from the peak of 750 thousand the year before. New evidence on hide shipments I uncovered in the Annual reports of the New York Chamber of Commerce is inconsistent with this view. For example, the Chamber of Commerce report for 1875/76 states that 200 thousand bison hides were shipped by rail to the port of New York alone in that year. ${ }^{43}$ This new data from the Chamber of Commerce report strongly suggests the Southern Herd was not destroyed by 1874 - a fact further corroborated by contemporary news stories and numerous personal accounts of buffalo hunters which make

included) takes a suspicious jump in the early 1870s exactly when the London Times article dates the innovation and reports on a booming trade in hides. Had the series boomed in 1868 or 1875 this coincidence in timing would not be present.

${ }^{43}$ The Chamber of Commerce of New York 18th Annual Report for 1875/1876 contains the throw away line "Included in the receipts by railroad are about 200,000 bison hides", p. 115. Since rail was only one of many transportation routes, and New York only one of several large export ports, it is reasonable to assume the total number of bison hides reaching the international market was much higher. 
it clear that the Southern Herd was not destroyed until $1879 .{ }^{44}$

When considering the 1872-1874 period alone, my constructed series and Dodge's (constructed) numbers are much closer. For example, Dodge's estimate of hide shipments over the 1872-1874 period is approximately 1.4 million hides; the implied shipment of hides for exports from Figure 3 is somewhat higher at 1.7 million. Therefore, the magnitude of the Southern Herd destruction, and its pace in the early years of the slaughter, roughly match those available in the literature.

\subsection{Across country and across hide variation}

Further evidence is available if we exploit the variation across countries in hide exports. Historical accounts of the hide trade reveal that two individuals were critical in its progression. One was a Kansas city pelt trader called J.N. Dubois. The standard historical account given by Gard (1960, p. 90) appeared earlier in the paper. Another trader repeatedly mentioned in early accounts was W.C. Lobenstein. Lobenstein was a well known trader in leather products who sometime in late 1870 or early 1871 started to fill orders for hides to ship to England. Given these historical accounts it is revealing to note that the geographic distribution of U.S. hide exports offers two other pieces of confirming evidence.

U.S. export data show the value of hide exports to Germany being negligible in the early 1860 s, and then skyrocketing to over $\$ 100,000$ in $1871-72$, rising further to over $\$ 500,000$ in 1874 , and then declining to $\$ 50,000$ in $1880 .{ }^{45}$ It is striking that the sudden rise in exports of hides to Germany occurs just when other historical accounts place J.N. DuBois at center stage in

\footnotetext{
${ }^{44}$ For e.g., the Fort Worth Democrat, Nov. 8, 1876, has a front page story titled "Freighters Wanted. The Largest Buffalo Hunt Ever Known". The story reports countless thousands of buffalo cover the prairies while the hunt is the largest ever known. Regarding the end of the hunt see the Frontier Times article "The Last Buffalo Hunt Held in the Lone Star State", reprinted by the Dallas Morning News Aug. 9, 1925. The article dates the last hunt to Nov. 1879.

${ }^{45}$ Prior to unification of Germany in 1870, these exports are to cities in the Hanseatic league; specifically Hamburg and Bremen. These towns disappear in the aggregate US export data in 1870 and are replaced by Germany as an entry. City specific export data (from the port of NY) is available in the NY Chamber of Commerce Annual Reports, and these data confirm that the Hanseatic cities are the leading destinations post 1870. Therefore, a change in the definition to German exports is unlikely to be responsible for the blip in exports.
} 
the buffalo hide trade. The English data is equally striking. In the post civil war period, 1866-1870, U.S. hide exports to England averaged \$50,000/year. Starting in 1872 however these exports took off rising to over $\$ 2$ million in 1873 and averaging over $\$ 1.3$ million dollars per year for the next six years. The sudden explosion in exports to England, together with the historical accounts of Lobenstein's activities provides further corroboration.

This evidence is however subject to critique. It may be inappropriate to attribute all of the "explosion in exports to England", or the "sudden rise in exports to Germany" to the impact of the innovation. Exports of hides to Europe may have risen for many reasons. The 1870s was a very tumultuous time in Europe with German unification in 1870, the Franco-Prussian war in 1871, and colonial expansion later in the decade. Perhaps the explosion in U.S. hide exports to Europe reflects a temporary European event and not the availability of buffalo hides from the U.S. One solution would be to examine U.S. exports to other European countries that did not have the ability to tan buffalo hides. This however is not possible. The U.S. exported hides to only a very few countries on a regular basis, and hence examining the exports to say Belgium, the Netherlands, etc. is not feasible because exports to these markets are both sporadic and small. Even if the data did exist, what guarantee would we have that these European countries could not learn from their neighbors in France, Germany, or the UK?

\subsubsection{Ruling out a European Demand Shock}

An alternative is to examine European data on hide imports from countries other than the U.S. If a European specific demand shock is driving U.S. hide exports upwards for reasons unrelated to the availability of buffalo, this shock should show up in European imports from other countries as well. To examine this possibility, I collected, where possible, hide import data from European countries that were major destinations for U.S. hide exports. The major destinations for U.S. hide exports were France, Germany, and the UK. At present, I have collected this data from all countries except Germany. ${ }^{46}$

\footnotetext{
${ }^{46}$ For the France data see France, Direction général des douanes, Tableau général du commerce de la France avec ses colonies et les puissance étrangères, published annually for the years 1825-1895. For the UK data see Great Britain, Annual Statement of the Trade and Navigation of the United Kingdom with Foreign Countries and British Possessions, for the years 1853-1870 and Annual Statement of the Trade of the United Kingdom with Foreign Countries and British Possessions for the years 1871-1924. I currently have some
} 
Using this data, I can examine how the share of hide imports coming from the U.S. varies over time. The rationale for using imports shares is simple: a uniform demand shock in Europe should raise its imports of hides from all sources leaving the U.S. share unchanged; a U.S. specific shock - such as the availability of buffalo hides - should however raise the share of imports coming from the U.S. dramatically and temporarily.

This new data also allows for a further sharpening of the hypothesis. The UK and French data allow me to divide their hide imports into tanned and raw hide categories; this is very fortunate since the available U.S. export data makes no such distinction. ${ }^{47}$ Since it is my contention that the buffalo hide exports to Europe were motivated by the inability of the U.S. domestic industry to tan buffalo hides, increased buffalo hide exports coming from the U.S. must come in the raw hide category.

In Table 2 below I present the results from a difference-in-means test on the U.S. share of raw hide imports into the U.K and France. In light of Figure 3, I divide the sample period into the period of Southern Herd destruction, 1871-1879, and refer to this as the Southern Treatment Group while the remaining period is captured in Other. I test the null of equality in mean import shares across these two periods against the alternative that the import share of raw hides was higher during the period the Southern Herd was destroyed.

\begin{tabular}{|c|c|c|c|}
\hline & \multicolumn{3}{|c|}{$\begin{array}{l}H_{o}: m_{o}-m_{1}=0 \\
H_{a}: m_{o}-m_{1}<0\end{array}$} \\
\hline & Difference & $t$ & $P<t$ \\
\hline France & $\begin{array}{l}-5.02^{a} \\
(1.36)\end{array}$ & -3.69 & 0.001 \\
\hline UK & $\begin{array}{l}-3.39^{a} \\
(1.25)\end{array}$ & -2.71 & 0.001 \\
\hline
\end{tabular}

Notes: $m_{1}$ is the mean of the Southern Treatment Group and $m_{o}$ is the mean of the Other group. Standard errors are reported in parentheses, $\mathrm{t}$ is Student's t-statistic, and P

German data but it is not up to the task as hides are grouped in with fur items, and there is an incomplete record of imports across countries. I would like to thank Andy Strangeman and Investra ltd. for their help in acquiring this data.

${ }^{47}$ The new data is useful in two other ways. The French data divides out skins from hides and assures us that goat and deer skins were only 1-2\% of total US hides and skins exports to France. The French and U.K data also give hide imports in quantities. 
indicates probability values. The superscripts. ${ }^{a}$,indicates significance at the 0.01 level. The dependent variable is the share of raw hide imports from the U.S. in total raw hide imports from all countries.

The results are consistent with my earlier claims. The equality of means is rejected at very high levels of significance. A finding of equality of mean import shares across these two periods would have suggested a European specific event raised raw hide imports from all countries and not just the U.S.. The alternative is that there was an increase in the U.S. import share over this period due to the availability of buffalo.

\subsubsection{Ruling out a U.S. Supply Shock}

While the difference-in-means test argues against a European demand shock, there still remains other explanations for the rise in raw hide exports from the U.S. For example, a U.S. specific event such as the completion of railroads, the creation of an open range cattle industry, or the concentration of production in large slaughterhouses could have raised U.S. hide exports. ${ }^{48}$ Perhaps the bulge in exports shown in Figure 3 represents a U.S. supply shock unrelated to the buffalo slaughter.

To investigate this possibility I exploit one more feature of the data and our knowledge concerning the innovation. The only non-European country receiving significant hide exports from the U.S. is Canada. ${ }^{49}$ Since there is no evidence that the tanning industry in Canada was ever involved in the commercial tanning of buffalo hides, whereas the innovation was known in various European countries, I treat the innovation in tanning as a quasiexperiment with Canada as the control with no ability to tan buffalo hides, and the UK and France as treatment countries with the ability to tan. ${ }^{50}$ Canada is a reasonable but not perfect control: Canada was far less developed

\footnotetext{
${ }^{48}$ Any explanation along these lines does however have to explain why these U.S. specific events led to a temporary, and not permanent, rise in hide exports.

${ }^{49}$ For the Canadian data see Canada, General Statement of Exports, Sessional Papers 1860-1890.

${ }^{50}$ Canadian trade statistics do contain categories of exports tied to the buffalo (buffalo hair was one such item), but despite this practice of specifically labeling buffalo products there is no category for exported buffalo hides from Canada. This is perhaps not surprising because the Canadian buffalo episode is quite different from the American. In Canada, trade in buffalo robes was very important to depletion as was the associated hunting by natives and Metis. As well, buffalo were driven to extinction in Canada prior to the arrival of connecting Canadian railways. All of this suggests no hide exports came from Canada,
} 
than France or the UK in the 1870s, and its distance from the U.S. market is much smaller.

The UK and France are reliable treatment groups, if the assignment to treatment is exogenous. The London Times article, discussed previously, establishes that the timing of the innovation was exogenous to any characteristic of France or the UK, since these countries were not the intended market for the hides. The subsequent shipment of hides to the UK was likely determined by the sheer economic might of the UK at the time, the existence of other trading relations between the two nations, knowledge that the UK tanning industry was advanced, or even a common language. Similar shipments, if they occurred, to Germany or France would be determined by similar factors. It is difficult to see why any of these factors - which determined assignment to treatment - should play a role in determining the over-time variation in the share of raw hide imports coming into these countries from the U.S. As a consequence, the assignment to treatment may well provide the exogenous variation we need to identify buffalo hides in the data.

The innovation was a necessary but not a sufficient condition for exports. The herds had to exist for exports to occur. I date the availability of the innovation at 1871, and as before assume the Southern Herd was available until 1879. The Northern Herd was available to hide hunters in the early 1880s, when the threat from the Sioux was eliminated, and was destroyed by 1886. The most general specification would allow for two treatment effects (North and South), country specific time trends and country dummies as follows:

$$
s_{i t}=\alpha_{i}+\beta_{i} t+\gamma T_{i t}^{S}+\delta T_{i t}^{N}+\epsilon_{i t}
$$

where $s_{i t}$ is the U.S. share of raw hide imports in total raw hide imports into country $i=\{$ Canada, France, $U K\}$ in year $t$ from 1866 to $1887 ; \alpha_{i}$ is a country specific constant, and $\beta_{i} t$ is a country specific time trend. $T_{i t}^{S}$ is the treatment effect which takes on the value 1 during 1872-1879 and is zero otherwise; $T_{i t}^{N}$ takes on the value 1 from 1881 to 1886 and is zero otherwise. Summary statistics for the import shares are presented in Table 3 below.

and hence the import of cow hides into Canada was determined by the same forces driving demand for hides in Europe: a demand for leather for machinery, saddlery, and footwear. 
Table 3 - Summary Statistics

U.S. Share of Raw Hide Imports

\begin{tabular}{lcccccc}
\hline \hline Country & Mean & Median & Std. Dev. & Min. & Max. & No.Obs. \\
\hline Canada & 91.5 & 93.1 & 6.6 & 70 & 97 & 22 \\
France & 2.9 & 1.7 & 3.3 & .03 & 13.4 & 22 \\
UK & 3.4 & 1.6 & 3.9 & .11 & 13.6 & 22 \\
\hline
\end{tabular}

As expected, the U.S. share of raw hide imports into Canada is very large at $91.5 \%$. The reason is simply location: in the late 19th century the world hide market was dominated by exports from Argentina and other South American countries. These countries are distant from Canada but along well established shipping routes to Europe. The median shares show that France and the U.K relied on U.S. exports very little, while their average shares exceed their medians because of exceptional shipments during the Southern Herd slaughter. One noteworthy aspect of the Canadian data is that the minimum import share was reached during the panic of 1873 when bankruptcies disrupted shipments through Great Lake ports.

Table 4 presents the results from estimating, via OLS, various specifications of 11 . As we move left to right in the table more restricted versions of 11 are estimated. 
Table 4 - A Quasi Experiment

\begin{tabular}{lccccc}
\hline \hline $\begin{array}{l}\text { Dependent variable is } s_{i t} \\
i=\{\text { Canada, France, } U K\}\end{array}$ & I & II & III & IV & V \\
\hline France Intercept & -.33 & .24 & & & \\
& $(2.24)$ & $(1.83)$ & & & \\
UK Intercept & 1.24 & .67 & & & \\
& $(2.24)$ & $(1.83)$ & & & \\
Europe Intercept & & & .46 & .47 & .60 \\
& & & $(1.67)$ & $(1.46)$ & $(1.42)$ \\
Canada Intercept & $91.12^{a}$ & $91.12^{a}$ & $91.12^{a}$ & $91.08^{a}$ & $90.73^{a}$ \\
& $(2.06)$ & $(2.05)$ & $(2.03)$ & $(1.57)$ & $(1.41)$ \\
France Time & .09 & & & & \\
& $(.19)$ & & & & \\
UK Time & -.01 & & & & \\
& $(.19)$ & & & & \\
Europe Time & & .04 & .03 & & \\
& & $(.15)$ & $(.15)$ & & \\
Canada Time & .03 & .03 & .03 & & \\
Time & $(.16)$ & $(.15)$ & $(.15)$ & & \\
& & & & .04 & .07 \\
North Treatment & 1.07 & 1.07 & 1.07 & 1.10 & \\
& $(2.51)$ & $(2.49)$ & $(2.47)$ & $(2.16)$ & \\
South Treatment & $4.80^{a}$ & $4.80^{a}$ & $4.80^{a}$ & $4.81^{a}$ & $4.38^{a}$ \\
& $(1.71)$ & $(1.70)$ & $(1.68)$ & $(1.65)$ & $(1.41)$ \\
$R^{2}$ adjusted & .99 & .99 & .99 & .99 & .99 \\
$R M S E$ & 4.67 & 4.63 & 4.60 & 4.56 & 4.53 \\
No.obs. & 66 & 66 & 66 & 66 & 66 \\
No & & & & &
\end{tabular}

Notes: ${ }^{a, b, c}$ : significant at $0.01,0.05,0.10$ respectively.

Column I allows for country specific time trends and intercepts, while column II restricts the UK and France to a common European time trend. Column III goes further to restrict both the intercept and time trend to be common to Europe, while column IV imposes a common time trend across all countries. Column V eliminates the Northern Treatment effect entirely.

It is apparent from the results in column I and II that we cannot distinguish between the constants for the UK and France, and hence from column III forwards they are grouped together under Europe. This is no surprise 
given the reported medians in Table 3. The constant terms for Europe and Canada are however significantly different much as we would expect. There is also little evidence of country specific time trends. A common to Europe trend is imposed in column II forward, while a common to all countries trend is introduced in column IV. The regressions' high level of fit comes from features of the data. Most of the variation in the data is cross-country. Europe and Canada differ greatly in the share of imports from the U.S.; therefore, the country specific constants alone capture much of the variation. Despite this feature, the estimates for both the Northern and Southern treatment are always positive while the Southern treatment is always highly significant.

The relative and absolute magnitudes of the treatment effects also bear scrutiny. The Southern treatment effect is estimated to be four to five times larger than the Northern which is consistent with the historical accounts of the slaughter by Hornaday and others. The magnitude of the Southern treatment effect is estimated at $5 \%$ points. Since the estimated U.S. share of imports into Europe, outside of the treatment period, is about .5\%, the Southern treatment estimate represents a very large ten fold increase.

One final means of evaluating these results is to employ them to construct a measure of implied buffalo hide shipments from the U.S. to the UK and France. I calculate counterfactual imports into the UK and France under the assumption that the innovation did not arrive in these countries. I employ the estimates from column $\mathrm{V}$ and set the treatment effects to zero to obtain a predicted import share for each country. Multiplying the predicted import share by actual imports generates a counterfactual import quantity. Subtracting counterfactual from actual imports gives an estimate of the implied buffalo hides imported by the UK and France. These are then graphed in Figure $4 .^{51}$

Figure 4 is striking. The implied buffalo hide imports are predicted to be either very small or negative until the early 1870s. This is as it should

\footnotetext{
${ }^{51}$ Two additional assumptions are made here. First, since U.K. and French imports are in terms of weight, I have to translate hundredweights and kilograms of hides into buffalo hide numbers. I assume a hide weighs $28 \mathrm{lbs}$ (then there are 4 in an English hundredweight), which is a conservative estimate given my reading of the history. Second, I have assumed the overall quantity of hide imports into the UK and France would have remained the same absent the innovation. I think this is reasonable. Recall that the US was only a small provider to these countries, their aggregate demand for hides was set by a derived demand for leather which should be independent of the innovation, and the hide market worldwide was huge and hence hide prices would not be affected by the absence or presence of US buffalo hides.
} 
Figure 4

Implied Buffalo Hide Imports

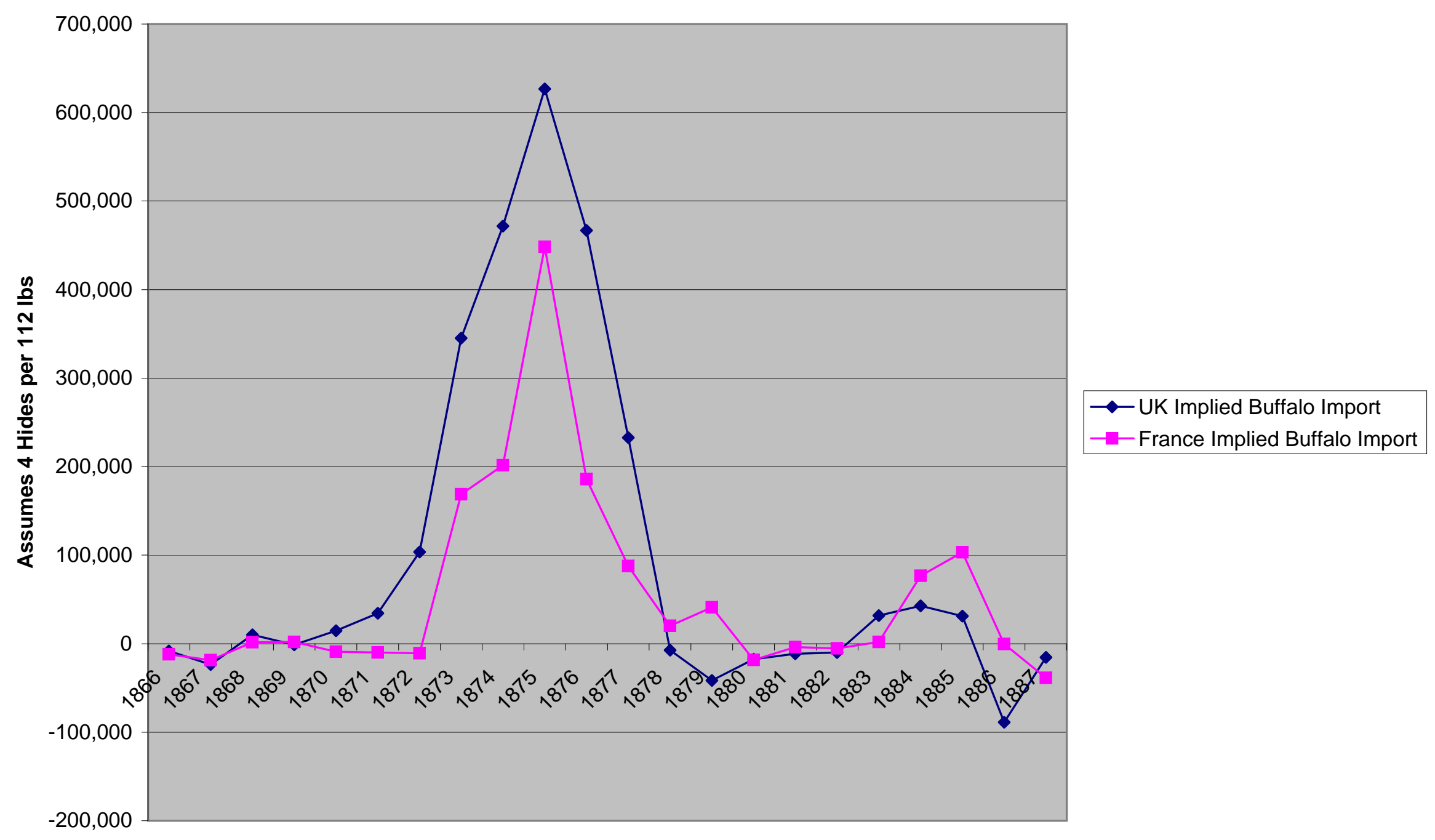


be since buffalo hide imports must be zero prior to the innovation. Post innovation, imports rise dramatically until 1875 only to fall again near to zero in the late 1870s. The figure shows what may be a small Northern Herd impact in the early 1880 s that falls off in 1886 . It is interesting to note that the UK series jumps upwards before that of France - consistent with the UK being the original innovator and France the follower. Simply adding the imported hides in 1875 shows the UK and France importing over 1 million buffalo hides, which is consistent with the aggregate figure presented previously in Figure 1. Summing the hide imports over the entire period (including the negative elements) yields imports to the UK and France of more than 3.5 million buffalo. If we gross these up by Dodge's wastage estimates, the implied kill would be larger still.

Overall, the examination of the across country and across hide variation in the data supports my earlier conclusions. The increase in raw hide imports from the U.S., during the time of the Southern Herd destruction, is a European/U.S. specific event. Hide imports into Canada did not rise as they did in the UK and France. ${ }^{52}$ Despite the fact that the data used is different, the method of identifying buffalo hides is different, and the variable under study is different (import shares of raw hides vs. export levels of all hides) the results are remarkably similar. There is strong evidence that the tanning innovation led to an unusual and temporary level of raw hide imports into the UK and France, but not Canada. It appears that this surge did not occur because of a broad based demand shock in Europe, nor because of a supply shock to cattle production in the U.S.. While alternative explanations for this data remain, the set of credible alternatives has been narrowed considerably. In particular, I will now argue that none of the other leading theories is consistent with the evidence presented.

\section{Alternative Hypotheses}

Amazon.com lists over 4000 book entries when buffalo is entered as a search term; a library of congress search generates the maximum of hits; and any visit to your local bookseller will reveal several new books on buffalo history, biology, etc. printed in just the last few years. Given the importance of the buffalo to Native and Western history, and its role as a national sym-

\footnotetext{
${ }^{52}$ This is further corroborated by a difference-in-means test (identical to that presented in Table 3) for Canada which cannot reject the null of identical means across periods.
} 
bol it should come as no surprise that there are numerous explanations for the buffalo's demise. Research contains numerous book length treatments, hundreds of scholarly articles and many theses and dissertations. It is not possible here to develop in any detail a careful examination of all of the competing hypotheses; instead I will discuss how key alternatives are largely inconsistent with the data and arguments presented here.

\subsection{The Army}

Many accounts of the buffalo slaughter contend that the elimination of the buffalo was a secret goal of government policy. Some authors go so far as to label it genocide. The evidence provided for this hypothesis is the many failed and stalled bills introduced in Congress, and various quotes from government officials noting the salutary effect an extinction would have on domiciling the natives. For example, a bill restricting the harvest of female cows to only Indian hunters on all federal lands passed both the House and the Senate in June of 1874, but was killed by a pocket veto by President Grant. This result is not that surprising since Grant's Secretary of the Interior, Columbus Delano, was in favor of the destruction of the buffalo. He refused to stop hide hunters from entering Sioux lands, and in his report for 1873 wrote "I would not seriously regret the total disappearance of the buffalo from our western prairies, in its effect upon the Indians. I would regard it rather as a means of hastening their sense of dependence upon the products of the soil and their own labors " Gard (1960, p. 207).

Other accounts coming from speeches made by General Sherman, Sheridan or Custer are all similar in that these men thought the destruction of the herds would have a beneficial effect in reducing Indian resistance. ${ }^{53}$ While this aspect of the story is surely true, and while federal legislation may have helped stem the tide of the slaughter, the regulatory problem was formidable. ${ }^{54}$ The Great Plains is an incredibly large area that was only sparsely

\footnotetext{
${ }^{53}$ For example, General Sherman's quote "I think it would be wise", he said of the Sioux insistence on hunting on the Republican River, "to invite all the sportsmen of England and America there this fall for a Grand Buffalo hunt, and make one grand sweep of them all", Utley (2003, p.166).

${ }^{54}$ The regulatory problem was well known. In 1866, a Harper's Magazine writer commenting on the introduction of a bill to restrict buffalo hunting noted that "The difficulty will be to secure its enforcement, as the extermination of these animals, which is now impending, is brought about by parties who, at a distance from any control, are a law
} 
populated in 1870. Over much of the relevant time period, the federal government already had its hands full managing Indian wars, economic crises, and the progress of reconstruction after a bloody civil war. While the absence of federal regulation made the slaughter simple to conduct and legal, it was the economic incentive created by the tanning innovation that fueled the frenzy.

\subsection{New Railroads and New Rifles}

Two other new technologies are often linked to the buffalo slaughter: the extension of railroads into buffalo country, and the introduction of powerful breech loading rifles after the Civil War.

Various railroads promoted buffalo hunting excursions to eastern dandies and allowed shooting from rail cars. Sunday buffalo hunting trips were advertised quite widely in the press, and surely played some role in the slaughter. However the natural growth rate of buffalo is reasonable high (with an intrinsic rate of growth between .15 and .25), and this implies that localized sport hunting along the tracks could never deplete the herds significantly. Perhaps more importantly the railroads were a major transportation link in the buffalo hide trade. While it is surely true that hundreds of thousands of hides were shipped along the western railroads it is difficult to argue that the extension of new railroads into buffalo country caused the slaughter. For example, the Union Pacific railroad arrived in the heart of buffalo country at Cheyenne Wyoming in 1867 a full 5 years before the Southern hide boom. In the north, there is no gap in time between the completion of the Northern Pacific's line into Montana and the slaughter of the Northern Herd. In this case, the arrival of the railroad would seem critical, but this is not entirely clear. Prior to and after the railroad arrived, goods came and went by river boat on the Missouri. While the railroad may have lowered transportation costs, this region had other transportation options. It seems likely in fact that the northern slaughter was delayed by the hostile Sioux Indians, and not any lack of transportation. It was not until the early 1880s that the northern buffalo range was made safe for buffalo hunters - and made safe for the Northern Pacific to complete its construction into Montana. The Canadian experience also tells us that railroads were not a necessary condition for the

unto themselves, and who are not likely to be influenced by any enactments that do not involve the means of execution." Harper's Magazine, April 15th, 1866, Scientific Intelligence section. 
extermination, since buffalo were exterminated in Canada before the arrival of western railways.

A similar argument applies to the new powerful breech loading rifles introduced after the Civil war. The new rifles by Remington, Sharps and Springfield greatly facilitated the slaughter, but it is difficult to argue they were pivotal. For example, breech loading rifles such as the infantry issue Springfield .50 calibre were in existence years before the slaughter occurred, while perhaps the most popular buffalo gun, the Sharp's Big 50, was not introduced until after the slaughter was already three years underway (in 1874).

Therefore, while the existence of the new railroad lines into southern Kansas, northern Texas and Montana surely facilitated the slaughter, as did the availability of more and better rifles, it is difficult to argue they were necessary for the slaughter.

\subsection{Environmental Change \& Native Overhunting}

A final explanation for the slaughter is environmental change and drought coupled with native over hunting. ${ }^{55}$ The Great Plains experienced a very wet period up to the early 1850 s and had a series of serious droughts in the subsequent 30 years. Some authors contend that these environmental changes weakened the buffalo and reduced their numbers considerably prior to 1870 . If we add to this stress native overhunting, created by the robe market and the breakdown of societal norms within the Indian community, it is possible to argue in favor of a much smaller buffalo number prior to the hide hunters.

The evidence presented earlier is largely at odds with this explanation. The buffalo slaughter was large and not small, and it was primarily propagated by white hide hunters. While it is virtually impossible to prove the herds were not larger in 1850 than at the start of hide hunting in the 1870s, it is clear that the slaughter during the 1870s and 1880s was spectacular in its magnitude. Environmental change may have contributed to an overall lessening of buffalo numbers, but had it not occurred I suspect hide hunting would have just lasted longer. Long term change in the West's environment did not kill the buffalo - it was the simple profit motive created by technological change and maintained by robust export markets.

\footnotetext{
${ }^{55}$ Isenberg (2000) is the leading proponent of this view.
} 


\section{Conclusions}

The purpose of this paper was to investigate the slaughter of the plains buffalo in the 19th century using a combination of theory, empirics and first hand accounts of buffalo hunters. I have presented an explanation for the slaughter that is not conventional. While hide hunting, the U.S. Army, native over hunting and the Railroads are typically held responsible for the slaughter, the role of international trade has featured minimally if at all. Instead, I have argued that free trade in buffalo hides was critical to the explosion of activity on the plains in the 1870s. By employing insights from theory, I have pieced together statistical evidence from numerous countries, diary and newspaper accounts, and logic to present a largely circumstantial, but hopefully compelling case that the plains buffalo was not eliminated by the usual suspects - it was instead the victim of global markets and technological progress.

The introduction to this paper claimed that (1) a price for buffalo products that was largely invariant to changes in supply; (2) open access conditions with no regulation of the buffalo kill; and (3), a newly invented tanning process that made buffalo hides into valuable commercial leather were jointly necessary and sufficient for the slaughter on the Great Plains. The theoretical results demonstrate that the combination of a tanning innovation, open access to buffalo hunting, and fixed world prices delivers a punctuated slaughter that matches that witnessed on the Great Plains. I take this as proof of sufficiency.

I have also demonstrated that the slaughter can only be generated when demand is very elastic. This establishes the necessity of a market price that is "largely invariant" to changes in supply. The tanning innovation was proven to be necessary by the absence of the slaughter during the five years prior to 1872 when the Union Pacific had reached the heart of buffalo country. And the necessity of open access for the slaughter is proven by numerous private parties who found buffalo to be such a valuable resource that they established property rights on their own by capturing and then breeding live buffalo. Several entrepreneurial ranchers in the 1870s and 1880s established private herds that, until federal legislation arrived in the mid 1890s, probably saved the buffalo from extinction.

It is somewhat ironic, that what must be the saddest chapter in U.S. environmental history was not written by Americans; it was instead, the work of Europeans. Europe in the 19th century was the high income developed 
region, while America was a young developing country recently rocked by a bloody civil war caused by racial strife. In the 1870s, America was a large resource exporter with little or no environmental regulation while Europe was a high income consumer of U.S. resource products apparently indifferent to the impact their consumption had on America's natural resources. Written in this way it is apparent that the story of the buffalo has as much relevance today as it did 130 years ago. Many developing countries in the world today are heavily reliant on resource exports, are struggling with active or recently past civil wars fueled by racial strife, and few, if any, have stringent regulations governing resource use. The slaughter on the plains tells us that waiting for development to foster better environmental protection can be a risky proposition: in just a few short years, international markets and demand from high income countries can destroy resources that otherwise would have taken centuries to deplete. 


\section{Appendix}

\subsection{Appendix A: Proofs}

Proposition 1. Suppose not. Let both $S_{1} \neq S_{2}$ solve $K(p, S)=G(S)$. Let $S_{1}<S_{2}$, then $G\left(S_{1}\right) / S_{1}>G\left(S_{2}\right) / S_{2}$ by the strict concavity of $G$. Since $K\left(p, S_{1}\right)=G\left(S_{1}\right)$ and $K\left(p, S_{2}\right)=G\left(S_{2}\right)$ by assumption, we must have $K\left(p, S_{1}\right) / S_{1}>K\left(p, S_{2}\right) / S_{2}$, or $N \int_{\alpha_{1} *}^{\bar{\alpha}} \alpha f(\alpha) d \alpha>N \int_{\alpha_{2} *}^{\bar{\alpha}} \alpha f(\alpha) d \alpha$. Note $\alpha_{1}=w / p S_{1}>\alpha_{2}=w / p S_{2}$, and hence $N \int_{\alpha_{1} *}^{\bar{\alpha}} \alpha f(\alpha) d \alpha>N \int_{\alpha_{1} *}^{\bar{\alpha}} v f(\alpha) d \alpha+$ $N \int_{\alpha_{2} *}^{\alpha_{1} *} \alpha f(\alpha) d \alpha$ implies $0>N \int_{\alpha_{2} *}^{\alpha *_{1}} \alpha f(\alpha) d \alpha$ which is a contradiction. The uniqueness of $\alpha *$ follows directly as does the unique division of labor across sectors.

Proposition 2. Under the conditions necessary for Proposition 1, Figure 1 depicts the determination of a unique steady state. By inspection $\dot{S}<0$ for $S$ above $S^{*}$, and $\dot{S}>0$ for $S$ positive but below $S^{*}$.

Proposition 3. i) For given $S, d \alpha^{*} / d p<0$ and hence $N \int_{\alpha *}^{\bar{\alpha}} \alpha f(\alpha) d \alpha$ rises with $p$ on impact. Differentiating $K(p, S)$ w.r.t. $p$ establishes $K_{p}=$ $-\alpha^{*} N S f\left(\alpha^{*}\right)\left[d \alpha^{*} / d p\right]>0$. ii) $\dot{S}<0$ for $S$ above $S^{*^{\prime}} ; d \alpha^{*} / d t=-\left[w /\left[p S^{2}\right]\right] \dot{S}$ $>0$ for $S$ above $S^{*^{\prime}}$; and, $d K / d t=K_{s} \dot{S}<0$ for $S$ above $S^{*^{\prime}}$. iii) Differentiating $K\left(p, S^{*}\right)=G\left(S^{*}\right)$, yields $d S^{*} / d p=\left[K_{p} /\left[G^{\prime}-K_{S}\right]\right]$. This is negative because we know $G(S)$ is cut from below at $S^{*}$ by $K(p, S)$ and hence $\left[G^{\prime}-K_{S}\right]<0$.

Lemma 1. The number of buffalo hunters is $\left[1-F\left(\alpha^{*}\right)\right] N$, where $\alpha^{*}$ is given by 1 and hence is a function of both $p$ and $S$. If $\alpha^{*}$ rises (stays constant, falls) hunter numbers fall (stay constant, rise). In autarky $p$ is determined by $S$ at every moment in time by market clearing. To prove the result, note from 1 that the elasticity of $\alpha^{*}$ with respect to $S$ and $p$ are equal at -1 . To determine how $S$ affects $p$, note $R S(p, S)=S N \int_{\alpha^{*}}^{\bar{\alpha}} \alpha f(\alpha) d \alpha /\left[F\left(\alpha^{*}(p, S)\right) N\right]$, and hence by inspection $R S$ falls with $\alpha^{*}$. This implies $R S(p, S)$ is increasing in both $S$ and $p$ and establishes that their partial elasticities must be positive 
$\varepsilon_{r s, p}>0, \varepsilon_{r s, s}>0$. Differentiating $R S$ shows $\varepsilon_{r s, s}=1+\varepsilon_{r s, p}>0$. Using this information differentiate the market clearing condition 9 to find 10. Finally, differentiating 1 and using 10 yields $\left[d \alpha^{*} / d S\right]\left[S / \alpha^{*}\right]=\left[\frac{1+\varepsilon_{r s, p}}{\sigma+\varepsilon_{r s, p}}-1\right]$. Therefore when $\sigma$ is greater (equal to, less) than one, $\alpha^{*}$ falls (stays constant, rises) with herd size, and buffalo hunter numbers rise (stay constant, fall) with herd size.

Lemma 2. Differentiating 9 with respect to $\beta$ holding $S$ constant yields $\left[d p^{e} / d \beta\right]\left[\beta / p^{e}\right]=\left[\frac{1}{\sigma+\varepsilon_{r s, p}}\right]>0$.

Proposition 4. Steady state is defined by $G\left(S^{*}\right)=K\left(\alpha^{*}, S^{*}\right)$, where $\alpha^{*}=m\left(p^{e}, S^{*}\right)$ is given by 1 , and $p^{e}=g\left(\beta, S^{*}\right)$ is given by 9 . Substitute for equilibrium prices and the marginal hunter in the steady state condition. Differentiate with respect to $\beta$ to find: $d S / d \beta=\left[K_{\alpha} m_{p} g_{\beta}\right] /\left[G^{\prime}-\frac{d K}{d S}\right]$ where subscripts denote partial derivatives. We have already established $K_{\alpha}<0$ and $m_{p}<0$. Lemma 2 established $g_{\beta}>0$. Therefore the numerator of $d S / d \beta$ is positive. Local stability of any steady state requires $\dot{S}<0$ for $S$ above $S^{*}$, and $\dot{S}>0$ for $S$ below $S^{*}$. Using 6 , this requires $\dot{d} S / d S=$ $\left[G^{\prime}-\frac{d K}{d S}\right]<0$, where $\frac{d K}{d S}$ is a total derivative taking into account price adjustment in autarky. Requiring local stability signs $d S / d \beta<0$.

\subsection{Appendix B: Data}

\subsubsection{Hide Prices}

There are a variety of sources for hide prices. Information on prices is important for three reasons. First, in some cases I need to deflate export values to obtain quantities so it is important that the prices be right in order for the quantities to be right. Second, if there was a huge change in hide prices during the period this may suggest alternative hypotheses that are not considered here. Third, it would be useful to know how much buffalo hunters obtained for their efforts in order to understand just how profitable hunting may have been.

Prices used to deflate values were obtained from several sources to ensure that no one source could be responsible for the results. The primary source for hide prices is the limited number of hide prices given in Foreign Commerce and Navigation figures for hides and skins exports. To construct the price index for hides I employ price per hide data from 1864, 1865 and 1866. Price 
per hide is found by dividing that year's export revenue by the number of hides exported. I then take a simple average of these three years, and employ the leather and leather goods price index of Warren and Pearson to generate an estimated price per hide for 1865 to 1886 . I employ exactly the same method when I use the price series drawn from the Annual Reports of the New York Chamber of Commerce.

\subsubsection{Hide Exports}

I assume the number of cattle hides produced is equal to the annual slaughter of U.S. cattle. To calculate the slaughter over the 1870-1886 period, I proceed in two steps. In step one, I calculate the breeding stock of cattle. I follow Rosen, Murphy and Scheinkman (1994) by relating the total head count $y(t)$ of all cattle to current and past values of the breeding stock $x(t)$. The total stock of cattle is equal to this year's breeding stock $x(t)$, plus last years calves, $g x(t-1)$ plus yearlings that have yet to be slaughtered $g x(t-2)$. That is:

$$
y(t)=x(t)+g x(t-1)+g x(t-2)
$$

where $\mathrm{g}$ is the natural growth rate set equal to .85. The U.S. data for $y(t)$ starts in 1867. Since 1867 is close to the period of time we are most interested in, I follow RMS by initializing the series employing the historical growth rate of the cattle population and making a steady state assumption. In particular, set

$$
\begin{aligned}
& x(1867)=y(1867) /\left[1+(g / 1.045)+(g / 1.045)^{2}\right] \\
& x(1868)=1.045 x(1867)
\end{aligned}
$$

where the first equation follows from the steady state version of $12 . \quad g$ is given by the average annual growth rate of the U.S. cattle population over the 1875-1990 period which is approximately $4.5 \%$. The second equation also reflects a steady state assumption. By using the initial breeding stock figures for 1867 and 1868, it is now straightforward to manipulate 12 to solve for $x(1869)$ and all subsequent years using data on the series $y(t)$ alone.

To calculate the implied slaughter of cows I employ the empirical estimates RMS obtain when they run the following regression over the 1900-1990 period.

$$
x(t)+c(t)=b_{0}+b_{1} x(t-1)+b_{2} x(t-2)+b_{3} x(t-3)+u_{t}
$$


where $x(t)$ is the breeding stock RMS generate when they assume $g=.85$ and $c(t)$ is the actual slaughter figure (only available from 1900 onwards). The addition of these two figures is then regressed on the lagged breeding stock plus a constant. I employ RMS's estimates of $b_{i}$ from their Table 1 , and by rearranging obtain an implied slaughter:

$$
c(t)=-1,524+1.01 x(t-1)+.09 x(t-2)+.92 x(t-3)-x(t)
$$

With the implied slaughter figures in hand I employ my three identifying assumptions. One, I assume hide exports in 1870 can only be from cattle; therefore, $h(1870)=f(1870) c(1870)$ where $f(t)$ is the fraction of total cattle hides exported in year $t$. Two, I assume the same is true for 1886, hence $h(1886)=f(1886) c(1886)$. And three, for any year between these two points I employ a linear interpolation for $f$; that is

$$
\begin{aligned}
& f\left(t^{\prime}\right)=f\left(t^{\prime}-1\right)+[[f(1886)-f(1870)] / 16] \\
& h\left(t^{\prime}\right)=f\left(t^{\prime}\right) c\left(t^{\prime}\right)
\end{aligned}
$$

The exported slaughter $h(t)$ is approximately $1 \%$ of the total slaughter in $1870 c(t)$, but rises to $1.7 \%$ in 1886 . Therefore, these estimates imply the vast majority of hides coming from the U.S. cattle slaughter are used in the U.S. This seems reasonable since the U.S. was a large importer of hides over this period.

The estimate for buffalo hides exported is calculated as:

$$
b h(t)=t h(t)-h(t)
$$

where $t h(t)$ is the total export number for hides calculated from U.S. trade statistics, $b h(t)$ is the estimated buffalo hides exported as shown in Figure 2, and $h(t)$ is the estimated cattle hide exports calculated using the procedure above.

An alternate procedure is to assume exports of cow hides are proportional to total domestically available hides which would include the U.S. slaughter plus imports into the U.S. market. US import data is available, and using the Warren and Pearson index we can again obtain hide numbers from the value estimates. Then again using 1870 and 1886 as points of identification, we find that exports as a function of total domestic availability is .7\% in 1870 rising to $1.1 \%$ in 1886 . Employing a linear interpolation between these 
years we can again construct implied cow hide exports and then buffalo hide exports. This alternative series is very similar to the one presented in the text (for eg. the total Southern hides exported is 5.15 million from 1871-1879, while the total Northern Herd exports equals .85 million from 1881-1885). The reason the two series are similar is that imports are only a fraction of the US domestic slaughter and imports are relatively smooth over this time period. This further check is useful. Although the export series we employ contains only exports from domestic production (and not imports), it is possible that a perfectly timed import surge of cow hides could have met domestic US demand therefore freeing up domestically produced hides to create the aberration in exports we are associating with the buffalo. This alternative procedure demonstrates that including variation in hide imports into our calculations cannot generate the boom in hide exports. 


\section{References}

Allen, Robert and Ian Keay, "Saving the Whales: Lessons from the Extinction of the Eastern Arctic Bowhead Whale", Journal of Economic History, June 2004, Vol. 64, No. 2, pp. 400-432.

Allen, Joel Asaph, "The American Bisons: Living and Extinct", Vol. IV, No. 10, Memoirs of the Museum of Comparative Zoology at Harvard College, University Press, Cambridge, 1876.

Benson, Bruce L., "Property Rights and the Buffalo Economy of the Great Plains", in Self Determination: the Other Path for Native Americans, ed. Terry Anderson, Bruce Benson, and Thomas Flanagan, Stanford University Press, 2006.

Besley, T., "Property Rights and Investment Incentives: Theory and Evidence from Ghana", Journal of Political Economy, 1995, Vol. 103, No. 5.

Bohn, Henning, and Robert T. Deacon, "Ownership Risk, Investment, and the Use of Natural Resources", The American Economic Review, Vol. 90, No. 3, June 2000, pp.526-549.

Brander J.A. and M.S. Taylor, "International Trade and Open Access Renewable Resources: The Small Open Economy Case", Canadian Journal of Economics, Vol. 30, No. 3, August 1997a, pp. 526-552.

Brander J.A. and M.S. Taylor, "The Simple Economics of Easter Island: A Ricardo-Malthus Model of Renewable Resource Use," American Economic Review, Vol. 88, No. 1, March 1998, pp. 119-138.

Burlingame, Merrill G., "The Buffalo in Trade and Commerce", North Dakota Historical Quarterly, Vol. 3, No. 4, 1928, pp. 262-291.

Canada, General Statement of Exports, Sessional Papers, for the years 1868-1890.

Carbyn, L., The Buffalo Wolf: Predators, Prey, and the Politics of Nature, Smithsonian Books, Washington, 2003.

Carlos, Ann M., and Frank D. Lewis, "Property Rights, Competition, and Depletion in the Eighteenth-Century Canadian Fur Trade: The Role of the European Market", Canadian Journal of Economics, Vol. 32, No. 3, May 1999, pp. 705-728.

Carlos, Ann M., and Frank D. Lewis, "Indians, the Beaver, and the Bay: The Economics of Depletion in the Lands of the Hudson's Bay Company, 1700-1763", The Journal of Economic History, Vol. 53, No. 3, September 1993, pp. 465-494. 
Cook, John R., The Border and the Buffalo, Crane and Company, Topeka, 1907, reprint by State House Press, Austin, 1989.

Copeland, Brian R., and M. Scott Taylor, "Trade Growth, and the Environment", Journal of Economic Literature, Vol. 42, No. 1, March 2004a.

Copeland, Brian R., and M. Scott Taylor, "Trade, Tragedy and the Commons", NBER Working Paper No. 10836, October 2004b.

Cutright, Paul R., Theodore Roosevelt the Naturalist, Harper, New York, 1956.

Davis, Theodore, R., "The Buffalo Range", Harpers New Monthly magazine, pp. 147-163,

Dodge, Richard I., The Plains of the Great West and their Inhabitants, Archer House, Inc. New York, 1877.

Farrow, S., "Extinction and market forces: two case studies," Ecological Economics, Vol. 13 1995, pp. 115-123.

Foster, J.E., "The Metis and the End of the Plains Buffalo in Alberta", in Buffalo edited by J.E. Foster, D. Harrison, and I.S. MacLaren, University of Alberta Press, 1992, pp. 61-77.

Flores, Dan., "Bison Ecology and Bison Diplomacy: The Southern Plains from 1800 to 1850", The Journal of American History, Vol. 78, No. 2, September 1991, pp. 465-485.

France, Direction général des douanes, Tableau général du commerce de la France avec ses colonies et les puissance étrangères, Renaud, Paris, for the years 1863-1890.

Gard, W., The Great Buffalo Hunt, Alred Knopf, New York, 1960.

Gard, W., "Mightiest Hunter on Buffalo Range", Dallas Morning News, 1955, March 12.

Gilbert, Miles., Leo Remiger, and Sharon Cunningham, Encyclopedia of Buffalo Hunters and Skinners, Pioneer Press, Union City, Tennessee, 2003.

Great Britain, Annual Statement of the Trade of the United Kingdom with Foreign Countries and British Possessions, London, H.M.S.O., for the years 1860-1890.

Grossman G.M. and A.B. Krueger, "Economic Growth and the Environment", Quarterly Journal of Economics, Vol. 2, 1995, pp. 353-77.

Hanner, John. "Government Response to the Buffalo Hide Trade: 18731883", Journal of Law and Economics, Vol. 24, No. 2, October 1981, pp. 239-271.

Hanson, John R., Trade in Transition: Exports from the Third World, 1840-1900, Academic Press, New York, 1980. 
Hornaday, William T., The Extermination of the American Bison, Smithsonian Institution Press, Washington, 1889.

Isenberg, A.C., The Destruction of the Buffalo, Studies in Environment and History, editor D. Worster and A.W. Crosby, Cambridge University Press, New York, 2000.

Kincaid, Naomi H., "Rath City", West Texas Historical Association Year Book, Vol. XXIV, October 1948, pp. 40-46.

Koucky, Rudolph.W., "The Buffalo Disaster of 1882", North Dakota History, Vol. 50, Winter 1983, pp. 23-30.

Krech, Shepard, III., The Ecological Indian: Myth and History, WW. Norton and Company, New York.

Lobenstine, Belle W., Extracts from the Diary of William C. Lobenstine: December 31, 1851-1858, Privately Published 1920, provided on request from the Kansas State Historical Society, Topeka KS.

Lobenstine W.C. Personal correspondence from the Merchants National Bank Records (MC 115), various years, obtained from the Montana State Historical Society, Helena, MT.

Lott, Dale, F., American Bison: A Natural History, University of California Press, Berkeley, 2002.

Lueck, Dean., "The Extermination and Conservation of the American Bison", Journal of Legal Studies, Vol. XXXI, No. 2, June 2002, pp. 609652 .

Matthiessen, P., Wildlife in America, The Viking Press, New York, 1959.

Mayer, Frank H., and Charles B. Roth., The Buffalo Harvest, Sage Books, Denver, 1958.

McHugh, Tom., The Time of the Buffalo, Alfred Knopf, New York, 1972.

Patterson, Don., and James E. Wilen, "Depletion and Diplomacy: the North Pacific Seal Hunt, 1886-1910, Research in Economic History, Vol. 2, 1977, pp. 81-139.

Rath, Ida Ellen., The Rath Trail, Dodge City, Kansas, Wichita KS: McCormick-Armstrong Co. Inc., 1961.

Rath, Ida Ellen, Early Ford County, Mennonite Press, North Newton, Kansas 1964.

Robinson, Charles, M. III, The Buffalo Hunters, State House Press, Austin Texas, 1995.

Roe, Frank Gilbert., The North American Buffalo: A critical study of the species in its wild state, University of Toronto Press, 1951. 
Roenigk, Adolph, Pioneer History of Kansas, KanColl Books, Kansas State Historical Society, 1933.

Roosevelt, Theodore., "Buffalo Hunting", St. Nicholas, Vol. 17, 1889, pp. 136-143.

Rosen, Sherwin \& Murphy, Kevin M \& Scheinkman, Jose A., "Cattle Cycles", Journal of Political Economy, Vol. 102, No. 3, June 1994, pp. 468-492.

Satterthwaite, Franklin., "The Western Outlook for Sportsmen", Harper's New Monthly Magazine, Vol. 78, No. 468, May 1889, pp. 873-880.

Schlebecker, John.T., Cattle Raising on the Plains 1900-1961, University of Nebraska Press, Lincoln, 1963.

Seton, Ernest Thompson, Lives of Game Animals, Vol. III, Part II, Hoofed Animals, Charles T. Branford, Company, Boston, 1909.

Seton, Ernest Thompson, "The American Bison or Buffalo", Scribners Magazine, October 1906, Vol. XL, No. 4, pp. 385-405.

Shaw, James H, "How many Bison originally populated Western Rangelands," Rangelands, Vol. 17, No.5, (October 1995), pp. 148-150.

Smits, David D., "The Frontier Army and the Destruction of the Buffalo: 1865-1883", The Western Historical Quarterly, Vol. 25, No. 3, Autumn, 1994, pp. 312-338.

State of New York Chamber of Commerce Annual Report, Press of the Chamber of Commerce, New York, for the years 1870-1886.

Steelquist, Robert U., Field Guide to the North American Bison: a natural history and viewing guide to the Great Plains Buffalo, Sasquatch books, Seattle, 1998.

Steinberg, T., Down to Earth: Nature's Role in American History, Oxford Univesity Press, New York, 2002.

Strickland, R.W., ed., "The Recollections of W.S. Glenn, Buffalo Hunter," Panhandle-Plains Historical Review, 22 (1949), 25-31.

The Times of London, "Buffalo Hides- Some eight or ten months ago", Aug. 17, 1872, pp 4, Issue 27458, Col. F.

UNEP Economics and Trade Unit, "Economic Reforms, Trade Liberalization and the Environment: A Synthesis of UNEP Country Projects," Synthesis Report, November 2001.

United States, Department of Treasury, Bureau of Statistics, Foreign Commerce and Navigation of the United States, Government Printing Office, Washington, for the years 1825-1890. 
Utley, R.M., The Indian Frontier 1846-1890, revised edition, History of the American Frontier Series, R. Allen Billington, General Editor, H. R. Lamar, M. Ridge, and D.J. Weber, co-editor, University of New Mexico Press, Albuguerque, 2003.

Warren, George and Frank Pearson, Prices, New York: John Wiley \& Sons, 1933.

West, Elliot, The Way to the West: Essays on the Central Plain, University of New Mexico Press, 1995, pp 71-83.

Wilen, James, E. "Common Property Resources and the Dynamics of Overexploitation: the Case of the North Pacific Fur Seal", U.B.C. discussion paper, No. 3, 1976. 